

\section{DISCLAIMER}

This report was prepared as an account of work sponsored by an agency of the United States Government. Neither the United States Government nor any agency Thereof, nor any of their employees, makes any warranty, express or implied, or assumes any legal liability or responsibility for the accuracy, completeness, or usefulness of any information, apparatus, product, or process disclosed, or represents that its use would not infringe privately owned rights. Reference herein to any specific commercial product, process, or service by trade name, trademark, manufacturer, or otherwise does not necessarily constitute or imply its endorsement, recommendation, or favoring by the United States Government or any agency thereof. The views and opinions of authors expressed herein do not necessarily state or reflect those of the United States Government or any agency thereof. 


\section{DISCLAIMER}

Portions of this document may be illegible in electronic image products. Images are produced from the best available original document. 


\section{NOTICE}

This repnrt was prepared as an account of work sponsored by the United States Government. Neither the United States nor the United States Department of Energy, nor any of their employees, nor any of their contractors, subcontractors, or their employees, makes any warranty, express or implied, or assumes any legal liability or responsibility for the accuracy, completeness or usefulness of any information, apparatus, product or process disclosed, or represents that its use would not infringe privately owned rights.

This report has been reproduced directly from the best available copy.

Available from the National Technical Information Service, U. S. Department of Commerce, Springfield, Virginia 22161.

Price: Paper Copy $\$ 5.25$

Microfiche $\$ 3.00$ 
Low-Cost Solar Array Project .

5101-76

This repor was prepared as an account of work ponsored by the United States Government. Neither the United States nor the United States Department of Energy, nor any of their employees, nor any of their contractors, subcontractors, or their employets, makes any warranty, express or implied, or assumes any legal liability or responsibitity for the accuracy, completeness

of usefiilness of any iniòirnatiun, apparaies, pivducl us

process disclosed, or represents that its use would not infringe privately owned rights.

\title{
Thermal and Other Tests of Photovoltaic Modules Performed in Natural Sunlight
}

\author{
J.W. Stultz
}

July 31,1978

Prepared for

Department of Energy by

Jet Propulsion Laboratory

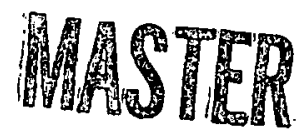

California Institute of Technology

Pasadena, California 


\section{ACKNOWLEDGMENT}

The author wishes to express his thanks to the following individuals for their contributions to this effort: Joe Stump, Tom Patrick, and $W$. Eastwood for installing the modules and associated hardware; Larry Bennett and Russ Whiteman for the thermocoupling; Don E. Lewis and Terry Fisher for the instrumentation. 
II. TESTING APPROACH AND ORGANIZATION

III. TEST HARDWARE AND INSTRUMENTATION

A. MODULE PHYSICAL PROPERTIES

$3-1$

B.

TEST SETUP

3-1

C. INSTRUMENTATION 3-1

IV. NOCT CHARACTERIZATION TESTS

$$
\text { i. . . }
$$
A. NOCT TEST PROCEDURE
4-1
B. NOCT OF VINDOR MOLULES
$4-1$
1. Air Voids $4-1$
2. Fins $4-3$
3. Transparent vs Opaque Substrates
$4-4$
4. Metal vs Nonmetal Substrates
4-4
5. High Efficiency Modules
$4-4$
C. NOCT OF RESIDENTIAL ROOF INSTALLATİNS. -
1. Lincoln Laboratory Configuration - 4-6
2. Shingle Simulated Mounting - $4-7$
D. NOCT OF DIRTY MODULES -
E. NOCT AND MAXIMUM POWER -
F. NOCT IN A SOLAR DOME - 4-9

V. OTHER TESTS -

A. WATER COOLED MODULE -

B. COMBINED PHOTOVOLTAIC AND SOLAR WATER
HEATING MODULE 
C. MODULE WITH A PHASE CHANGE MATERIAL ------------- 5-9

D. ELECTRICAL PERFORMANCE OF DIRTY MODULES ------ 5-12

VI. CONCLUSIONS - 6-1

A. PHOTOVOLTAIC MODULE THERMAL PERFORMANCE -

B. OTHER TESTS - 6-1

1. Water Cooled Module

2. Combined Photovoltaic and

Solar Water Heating Module - 6-2

3. Combined Photovoltaic and

Thermal Storage System - 6-2

4. Electrical Perfonnance of

Dirty Modules -

APPENDIX A. DETERMINATION OF NOMINAL OPERATING

CELL TEMPERATURE

A-1

A. PURPOSE -

B. DETERMINATION OF NOCT - A-1

C. AIR TEMPERATURE AND WIND CORREC'IIUN

D. TEST GEOMETRY - A=4

1. Tilt Angle - A-4

2. Height - A-4

3. Cubarray Configurntinn - A-4

4. Surrounding Area - A-4

5. Wind Direction -

6. Module Electrical Load -

E. TEST F.QIIIPMENT -

1. Pyranometer -

2. Wind Measurement - 
3. Air Temperature -

4. Cell Temperature -

5. Substrate Surface Temperature -

F. DATA RECORDING -

G. CLEANING -

H. EQUIPMENT CALIBRATION -

I. TEST DESCRIPTION -

J. AUTOMATION - A-6

\section{Figures}

3-1. Block I Modules - 3-4

3-2. Block II Modules - 3-4.

3-3. Block II Minimodules - 3-5

3-4. Research and Development Modules --_- 3-5

3-5. JPL Thermal Test Site

3-6. Pyranometer - 3-6

3-7. Wind Measurement Instrument -- 3-7

3-8. Air Temperature Enclosure - 3-8

3-9. Total Solar Intensity - 3-9

3-10. Local Air Temperature - 3-10

3-11. Wind Speed Summary -- 3-11'

3-12. Wind Direction - 3-12:

3-13. ( $\left.\mathrm{T}_{\text {cell }}-\mathrm{T}_{\text {air }}\right)$ vs Solar Intensity -

4-1. Roof Mount Simulation - 4-5.

4-2. Effect of Dirt Accumulation on NOCT (Non-Glass Front Surtaces)

4-3. Effect of Dirt Accumulation on NOCT (Glass Front Surfaces)

4-4. Solar Dome Concepts - 4-9

4-5. Dome Test Setup - 4-10 
5-1. Module Temperature Profile at Noon -- 5-1.

5-2. Electrical Efficiency of a Water-cooled

Flat Plate Photovoltaic Module - 5-3

5-3. Combined Module Configuration - 5-4

5-4. Solar Cell Temperature vs Time of Day

for Photovoltaic Only and Combined

Photovoltaic/Thermal Collectors - 5-6

5-5. Electrical Efficiency vs Time of Day

for Photovoltaic Only and Combined

Photovoltaic Thermal Collectors --_-_-_-_-_ 5-7

5-6. Effect of Water Storage Temperature on the

Electrical Efficiency of a Combined

Photovoltaic/Thermal Collector - - 5-8

5-7. Phase Change Photovoltaic Module -

5-8. Cell Temperature During Tests with

Phase Change Materials _- 5-12

5-9. Short-Circuit Current vs Angle of Incidence ---_--- 5-13

5-10. Short-Circuit Current vs Angle

of Incidence and Dirt Buildup - 5-14

6-1. NOCT Summary - 6-2

6-2. Combined Photovoltaic and Thermal Storage

Systcm for Spare and Hnt Water Heating --_-_-_-_-_ 6-3

A-1. Typical Cel1 Temperature Data --

A-2. NOCT Correction Factor -

A-3. Test Description Form - A-6

Tablco

3-1. Mndule Characteristics -- 3-3

4-1. LeRC and JPL NUC'I' 'lest Suminary --

4-2. NOCT Summary - 4-2

4-3. NOCT Summary for a Residential

Roof Installation - 4-6

4-4. Solar Dome NOCT Summary - 4-11 
5-1. Electrical Efficiency $\left(\eta_{\epsilon}\right)$ of Photovoltaic

Only and Combined Photovoltaic/Thermal Collectors ---- 5-7

5-2. Preliminary Economic Implications of Combined

Collectors - $5-9$

5-3. Material Properties of Candidate

Fusion Materials -_- 5-10

5-4. Electrical Efficiency $\left(\eta_{\epsilon}\right)$ Results -- 5-11

6-1. NOCT and $\eta_{\text {NOCT }}$ Summary 


\section{SECTION I}

INTRODUC'I'ION

The electrical power output of photovoltaic solar cell modules is dependent upon the operating temperature of the cells, and decreases at a rate of approximately $0.5 \%$ per ${ }^{\circ} \mathrm{C}$ with increasing cell temperature. Because of this temperature sensitivity, it is important to understand the thermal characteristics of modules so that modules and their supporting structures can be designed to reduce cell temperature to the extent that it is cost-effective. An understanding of module operating temperature characteristics is also necessary to allow accurate prediction of module power output under field operating conditions, and to allow accurate comparison of the field electrical performance of different module designs.

The activity described in this report was conducted throughout 1977 and during the first half of 1978, as a part of the Engineering Area of the JPL Low-Cost Solar Array (LSA) Project. This report is a follow-up of the first thermal report (Reference 1) and covers all the thermal activity in this interim period. The bulk of the testing has been the characterization of twenty-nine modules according to their nominal operating cell temperature (NOCT) and the effect on NOCT of changes in module design, various residential roof mounting configurations, and dirt accumulation.

Other tests, often performed parallel with the NOCT measurements, evaluated the improvement in electrical performance by cooling the modules with water and by channeling the waste heat into a phase change material (wax). Electrical degradation resulting from the natural marriage of photovoltaic and solar water heating modules was also demonstrated. Cost effectiveness of each of these techniques are evaluated in light of the LSA cost goal of $\$ 0.50$ per watt. 
The test program during the period covered in this report has had two objectives. Increasing our understanding of module thermal performance so that cooler-running modules can be designed continues to be the main objective. Secondly, obtaining the information to more accurately evaluate the cost effectiveness of potentially promising techniques (which could utilize the photovoltaic module in essentially its present form) has become a significant part of the thermal test program. Examples of promising techniques evaluated during this period are a water cooled module, a module with a phase change material, and the combination of a photovoltaic module and a solar water heating module.

The natural light test procedure for determining the nominal operating cell temperature (NOCT), which was discussed in the first thermal study (Reference 1), has been utilized extensively and has proven to be an excellent tool for understanding and characterizing the thermal performance of the various modules. During this period, the concept of NOCT has gained increased acceptance, and the results of these determinations provide an important characterization of module performance. Because of the block procurements and the parallel $R \& D$ procurements, the NOCT effort is a continuing one. NOCT-related tests are discussed in Section. IV.

Since the data system for NOCT has been automated, other tests are often carried out in a parallel mode. For the most part, these "other tests" are thermal in nature. However, measurement of the electrical performance during the day or around solar noon is often required to evaluate a configuration or a particular effect. Many of these tests support needs identified in the engineering or system area. "Other tests" are discussed in Section V.

The amount of analysis undertaken during this period has been minimal and of "back-of-envelope" caliber. If an approximation of performance indicates a promising concept, it is more expedient to huild and test the rnnfiguration than to carry out a detailed computiortype analysis. The flexibility of the data system, the large number and variety of modules available, and the various JPL shop facilities enable this desirable operating mode. Moreover, this approach is in conformity with the accelerated design of the LSA program. 
TEST HARDWARE AND INSTTRUMENTATION

\section{A. MODULE PHYSTCAL PROPERTIES}

The NOCT has been measured on all of the modules shown in Figures 3-1 through 3-4. The Block I modules (Figure 3-1) were obtained in the first JPL procurement and are representative of off-the-şhelf modules produced at the start of the LSA program. The Block II modules (Figure 3-2) are the first modules purchased which were constructed according to JPL specification. As the name implies, the Block II minimodules are smaller versions of the Block 2 modules and are used mainly for test. purposes. Several modules (Figure 3-4) have become available as an outgrowth of the various research and development tasks.

It io obvious rlum 'Higure's '3-i Lhrough 3-4 that the module construction. varies significantly. Basically, the solar cells are interconnected electrically, and are contained by an encapsulant between a cover and a substrate. Table 3-1 summarizes the materials used in the construction of each of the modules. Also included in Table 3-1 are the JPL modified modules. Each of these modules is a modification of a Block I, Block II, or R\&D module. In each case the modification was required to demonstrate the effect of a specific change in the module. on thermal performance. These modules are discussed in more detail in Section IV.

\section{B. TEST SETUP}

All tests were performed at JPL in the thermal test areas located on the roof of Building 248. The test site meets the requirements of the NOCT test procedure. Figure $3-5$ is a photograph of the test area. The site offers an unobstructed view of the sun for more than eight hours per day throughout the year.

Each module is part of a $1.22 \mathrm{~m} \times 1.22 \mathrm{~m}$ ( 4 foot square) array, which consists of other modules or black aluminum panels. The array attaches to a stand that can be positioned to any tilt angle belween $0^{\circ}$ and $90^{\circ}$. Adjustments of the tilt angle are made periodically to meet the required $\pm 5^{\circ}$ normality to the sun at solar noon.

\section{INSTRUYIENTATION}

Figure 3-6 shows the Eppley Pyranometer used to measure the total solar irradiance. The instrument is mounted in the plane of the array. 
A pliotograph of the MRI Mark III Vector Vane Sensor is shown in Figure 3-7. The instrument provides both wind direction and wind speed. It is positioned at the level of the arrays.

Figure $3-8$ is a photograph of the vented box which houses the thermocouple for measurement of the local air temperature. The air temperature monitor hangs from the back side of the array support structure. The measurement is made in the shadow of the array and approximately at its center.

Chromel-constantan thermocouples are used. Thirty-six gage wire is used to monitor the cell temperature and twenty-six gage wire is used for all other thermocouples.

The various instrumentation signals are processed by the IDAC (Integrated Data Acquisition and Control) system. Every two minutes all data is read ontu llaginetic tape for non-real-time processing by the Univac 1108 computer. Real-time printout and display are provided at the IDAC console. Solar intensity, wind velocity, and other channels are monitored continuously on X-Y plotters.

Univac 1108 processing includes a time tag printout of all the channels plus plotting of selected channels. Figures 3-9 through 3-13 are typical of the plotted data provided by the 1108 system. Figures 3-9 through 3-12 summarize the environment (total solar intensity, air temperature, wind speed and direction) during the test period. Figure $3-13$ is a plot of the difference between cell temperature and air temperature as a function of solar intensity for both the morning and afternoon. The curve formats enable a quick determination of the NOCT. With the present system, up to nineteen modules can be monitored simultaneously, and addilional growth potential exists with the very flexible IDAC systell.

Figure 3-1.1 illustrates one of the TDAC system capabilities. The system promies a cuntinuous four-minute averaying of the wind speed. Ndditional studies of the effects of wind will be required; however, as Figure 3-1l vividly illustrates, averagling of the wind data is a significant aid to interpreting the wind speed. 
Table 3-1. Module Characteristics

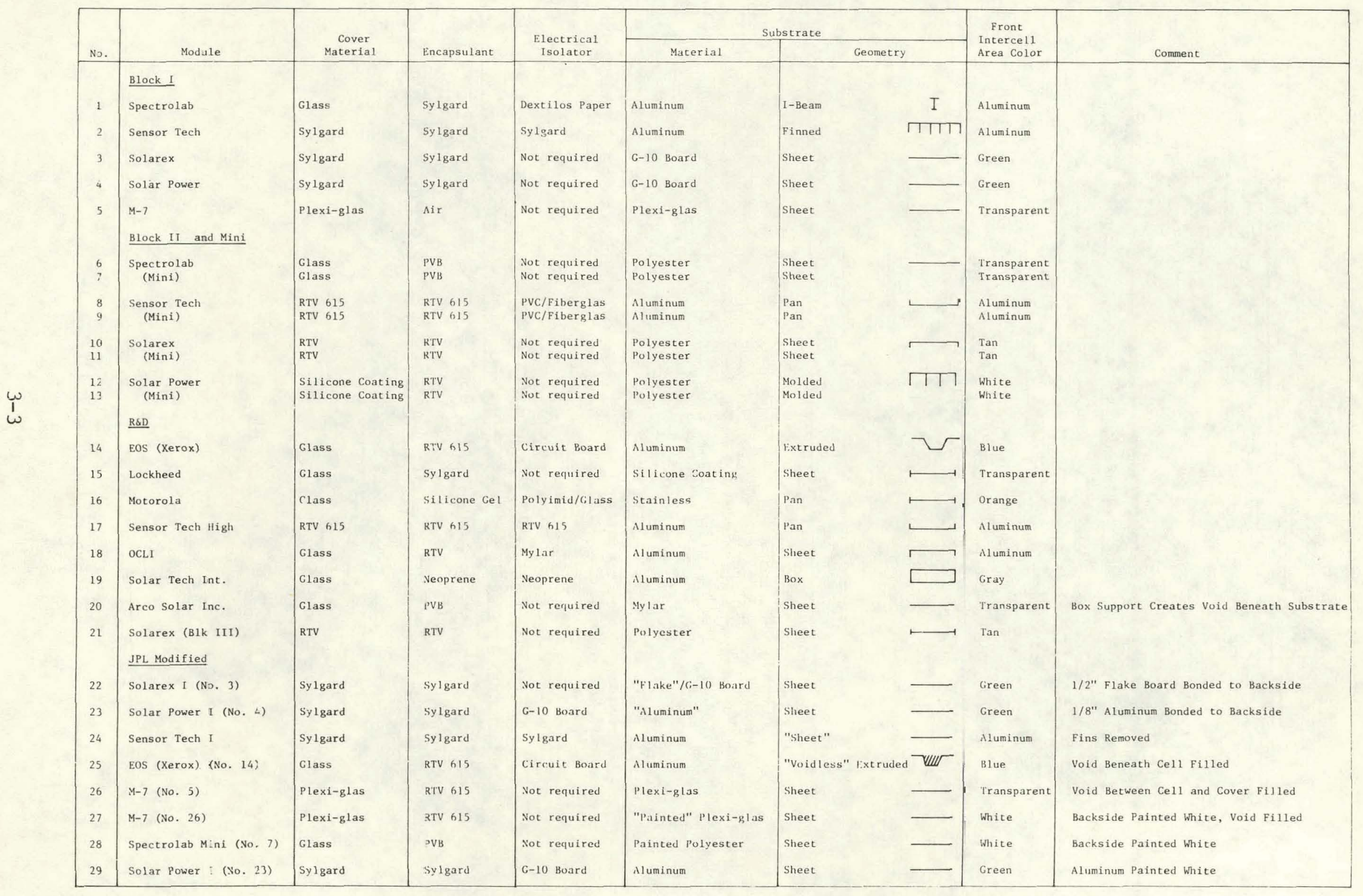




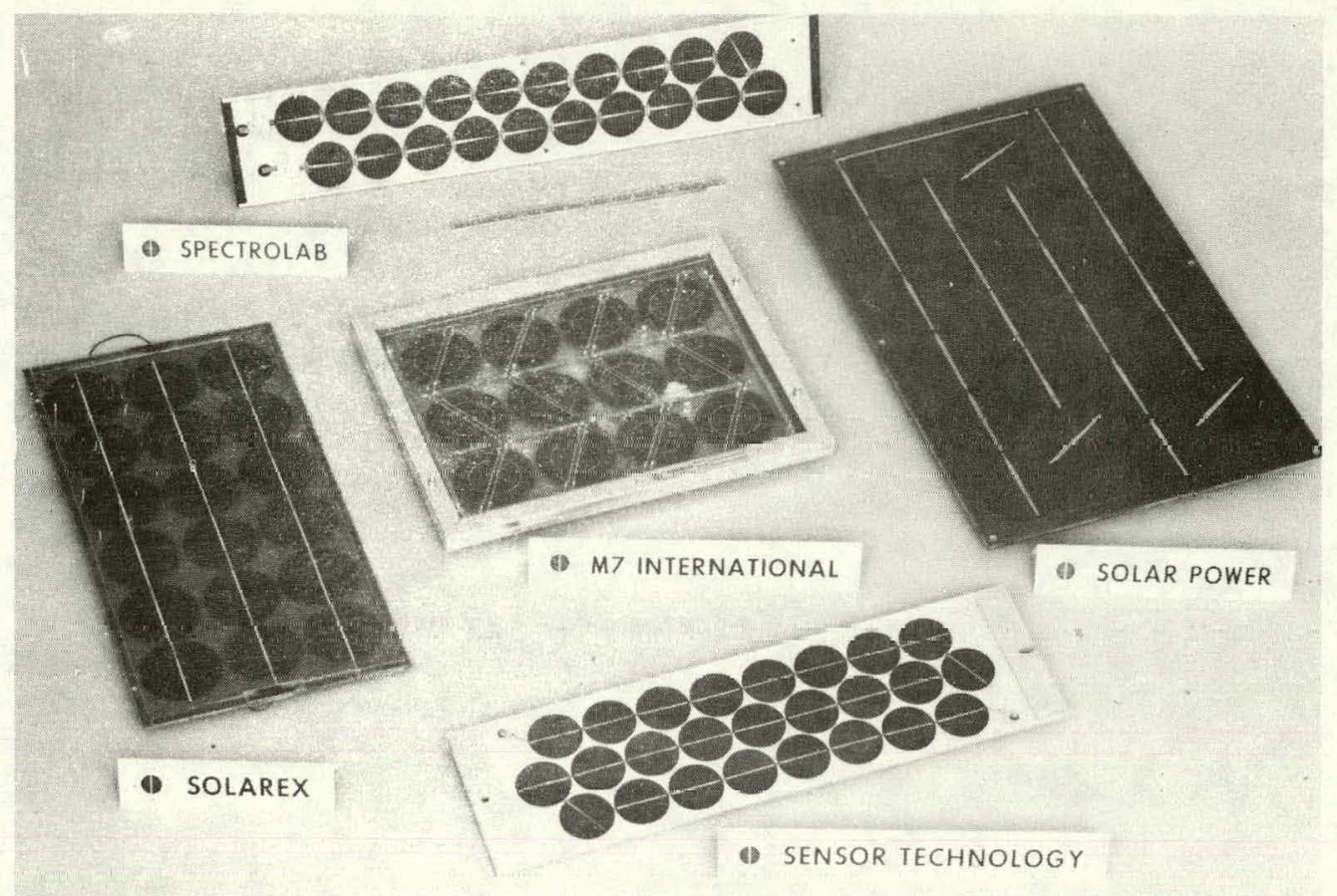

(1) $46 \mathrm{KW}$ MODULES

Figure 3-1. Block I Modules

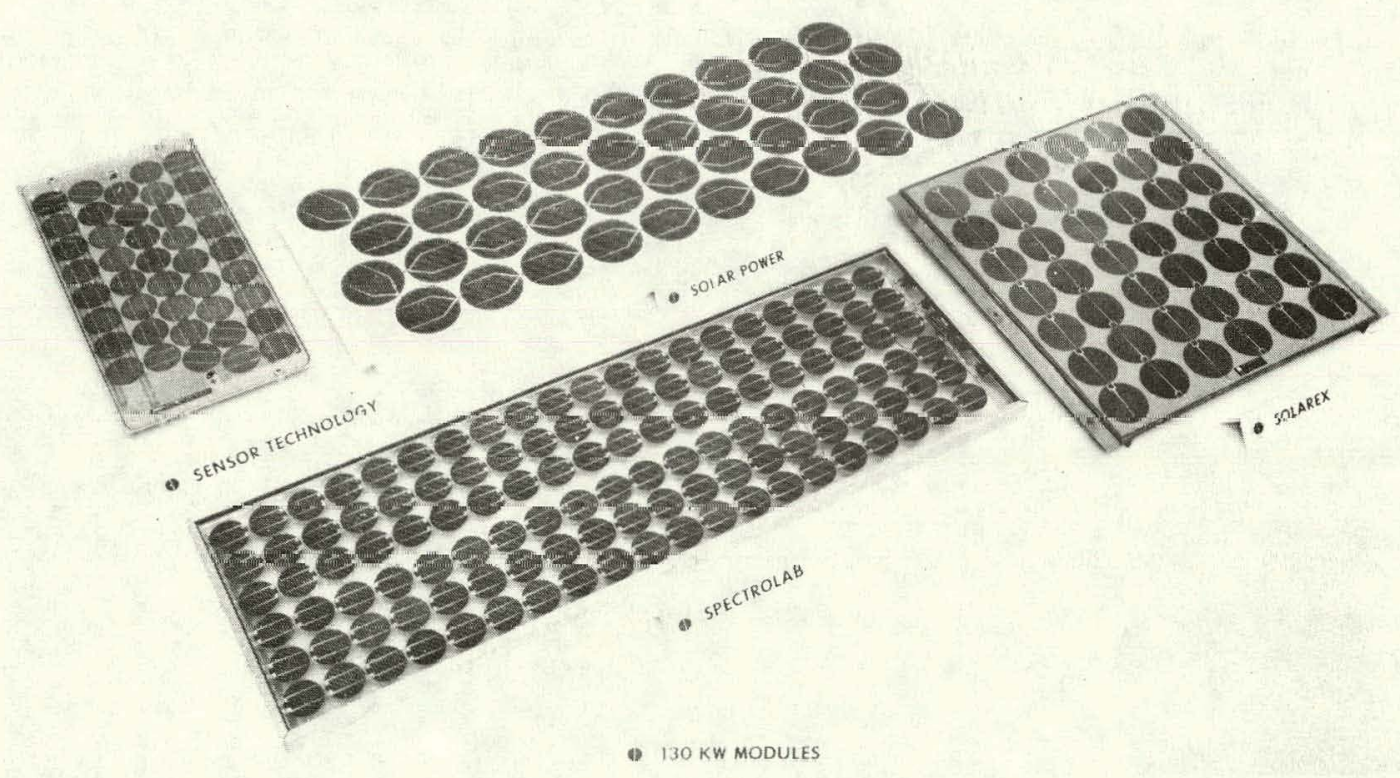

Figure 3-2. Block II Modules 

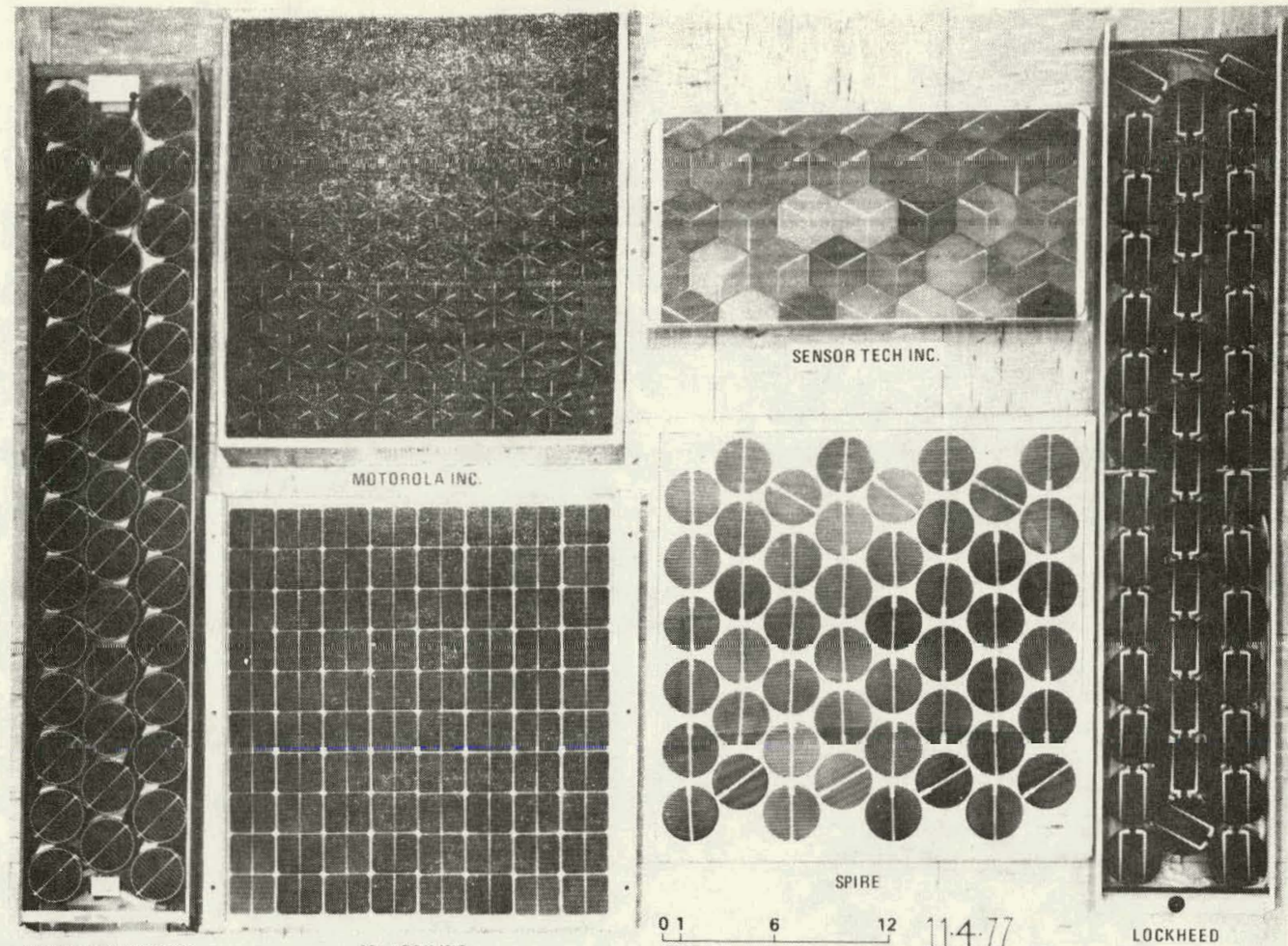

SOLAR TECHNOLOGY

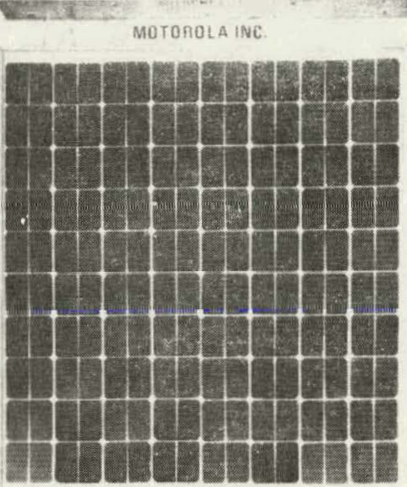

SOLAREXINC

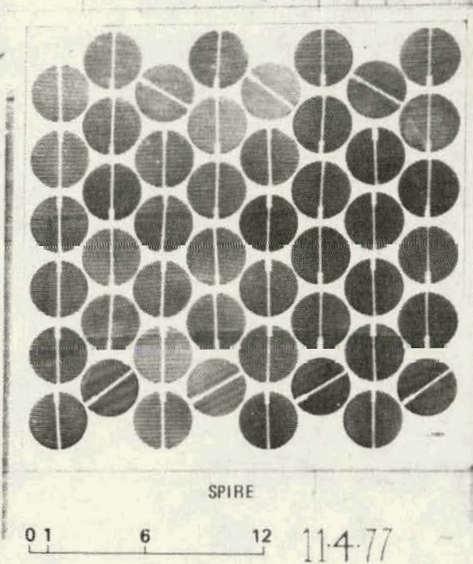

LOCKHEED

Figure 3-3. Block II Minimodules
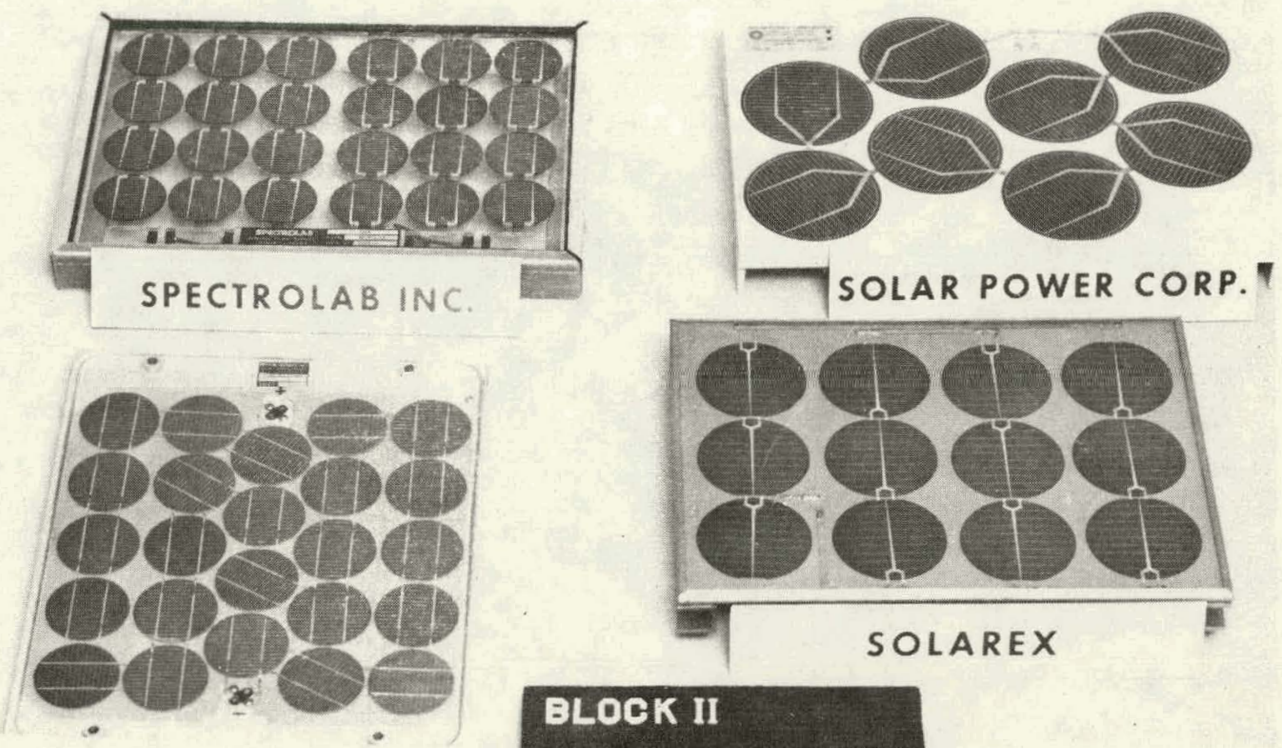

SENSOR TECH, INC

\section{BLOCK II \\ MINI - MODULES \\ 110977}

Figure 3-4. Research and Development Modules 


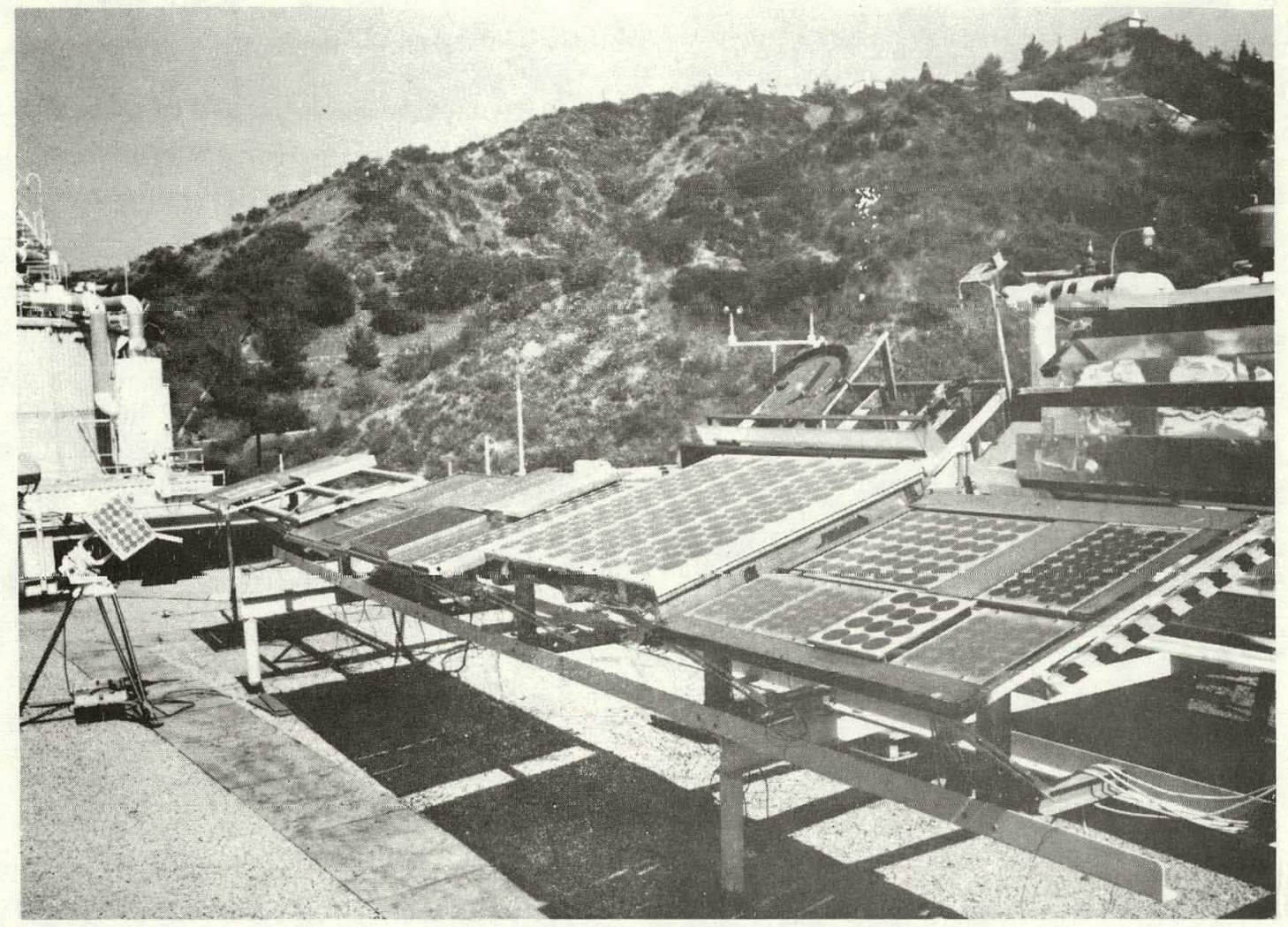

Figure 3-5. JPL Thermal Test Site

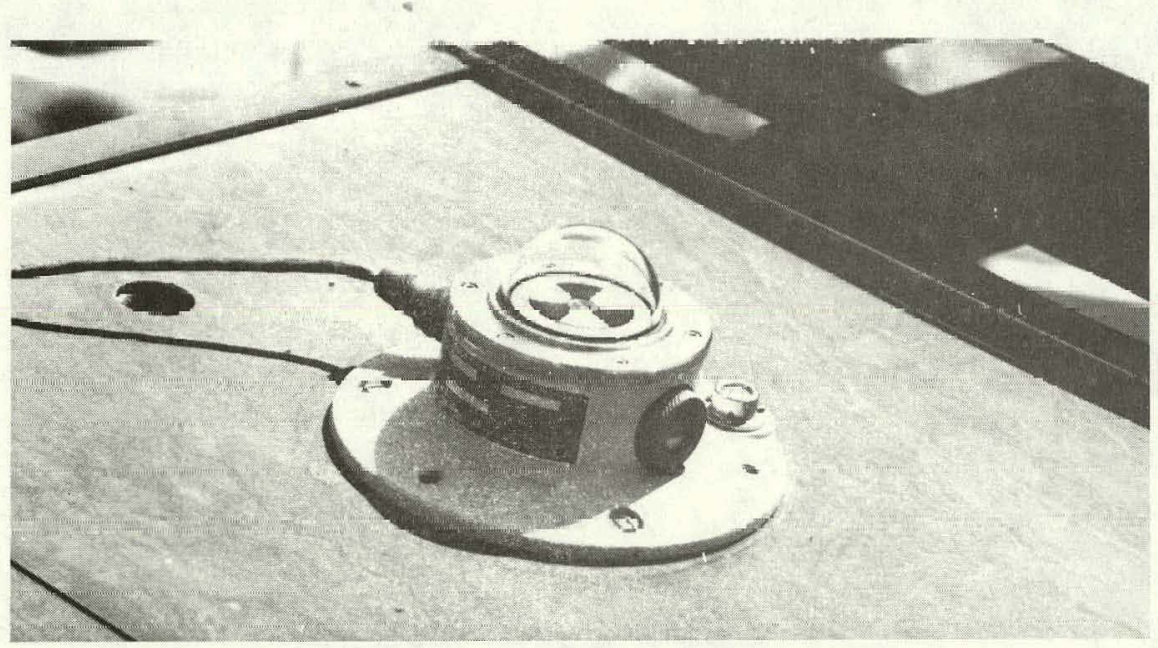

Figure 3-6. Pyranometer 


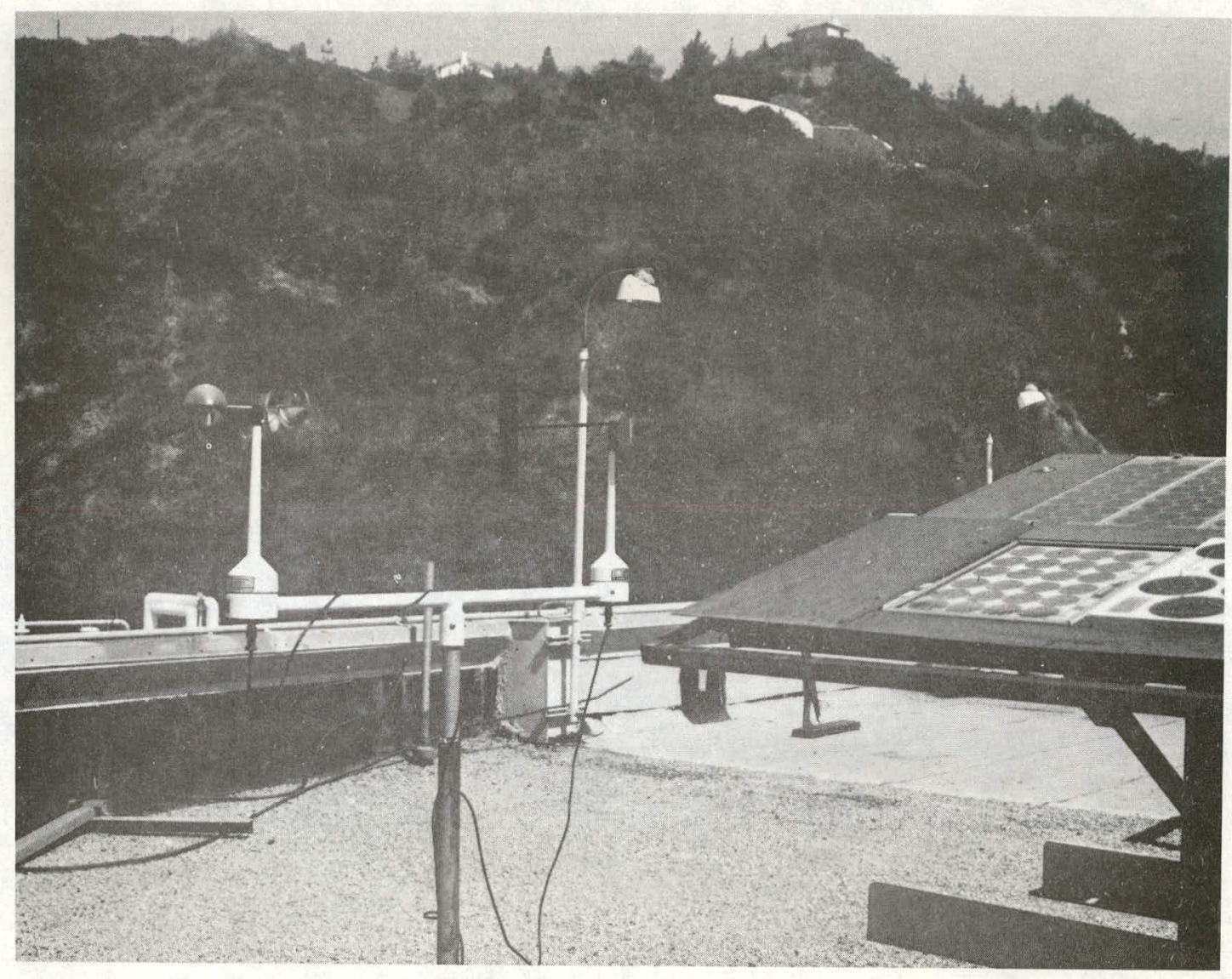

Figure 3-7. Wind Measurement Instrument 


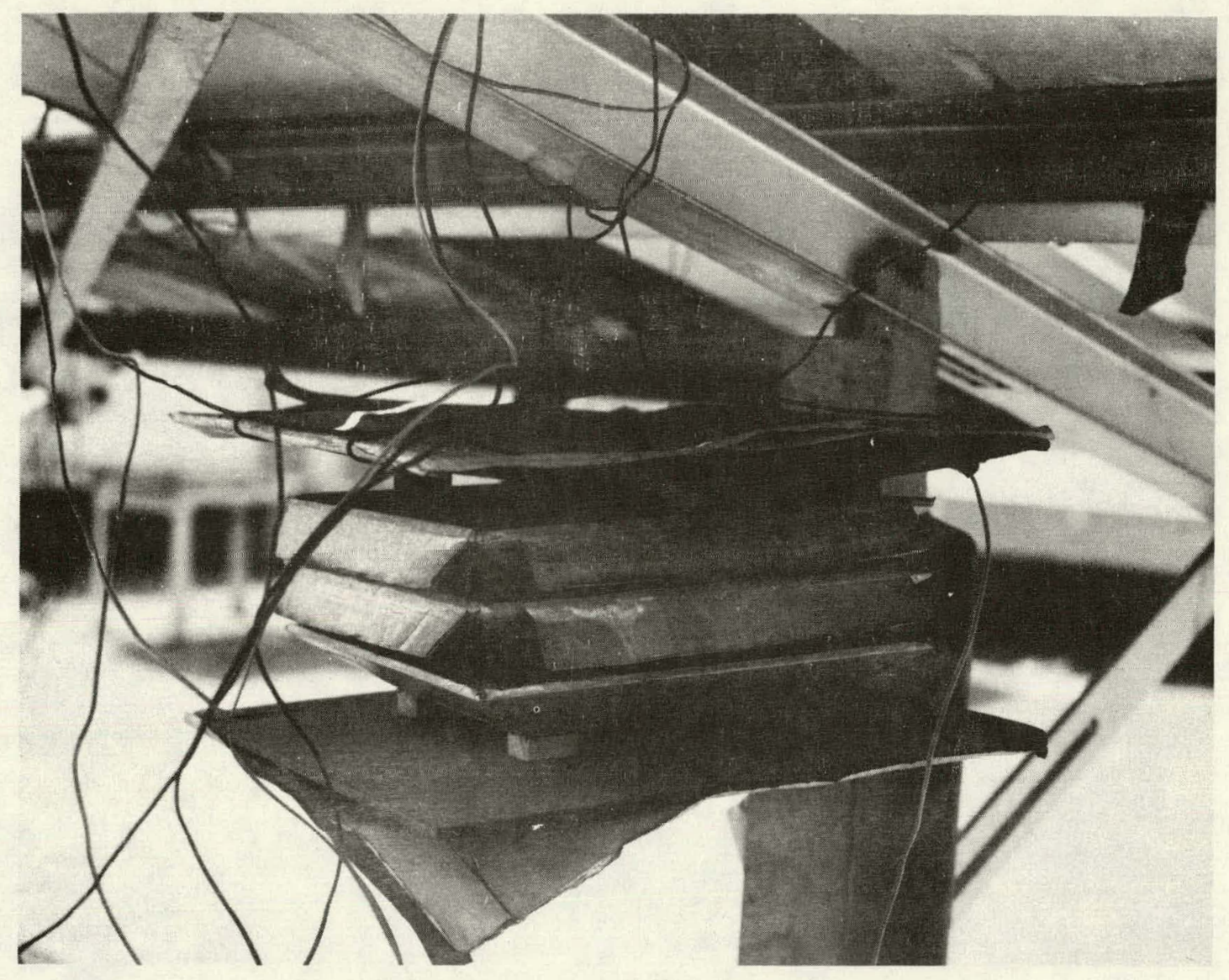

Figure 3-8. Air Temperature Enclosure 


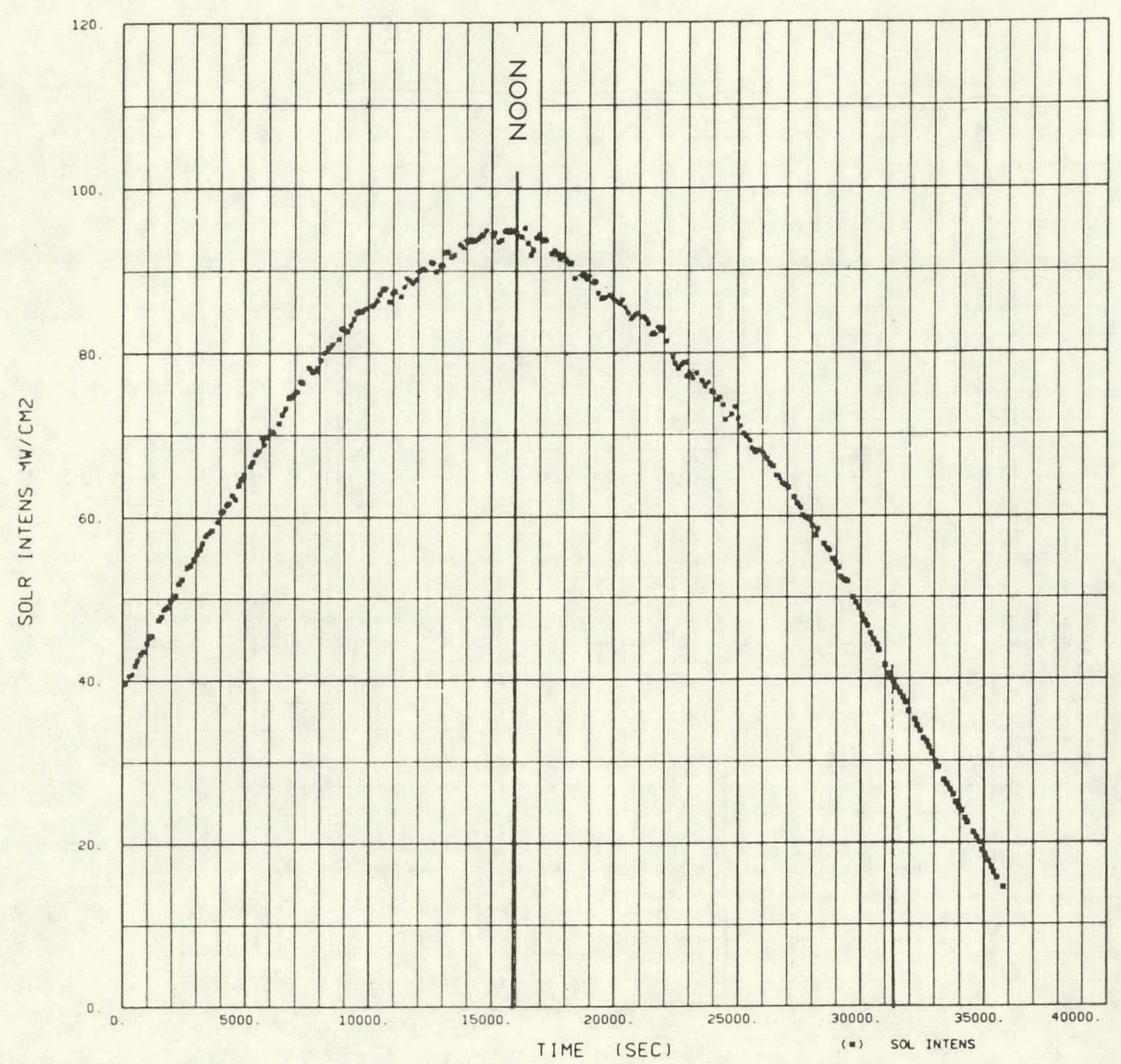

Figure 3-9. Tnta1 Snlar Intensity 


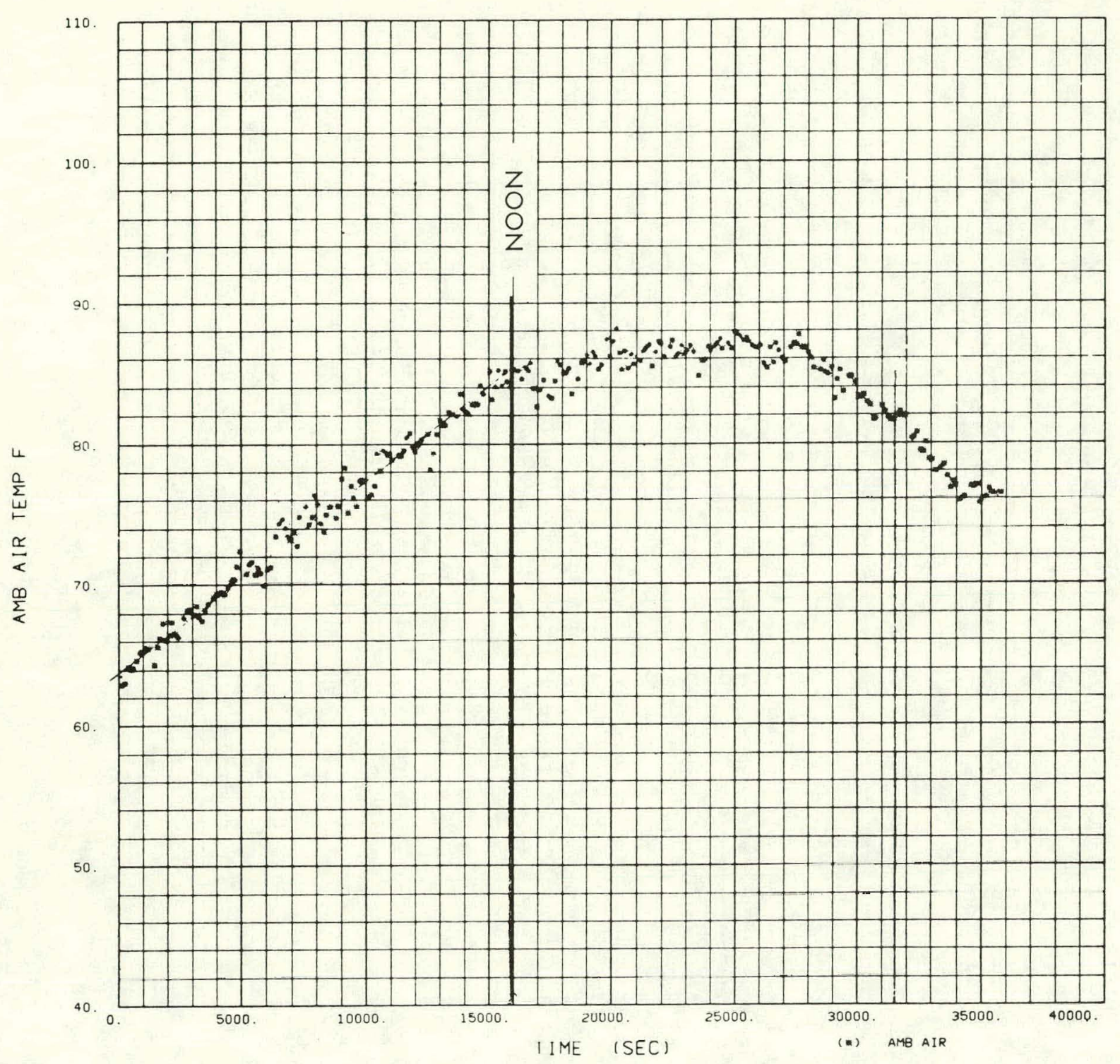

Figure 3-10. Tinsal Air Temperature 

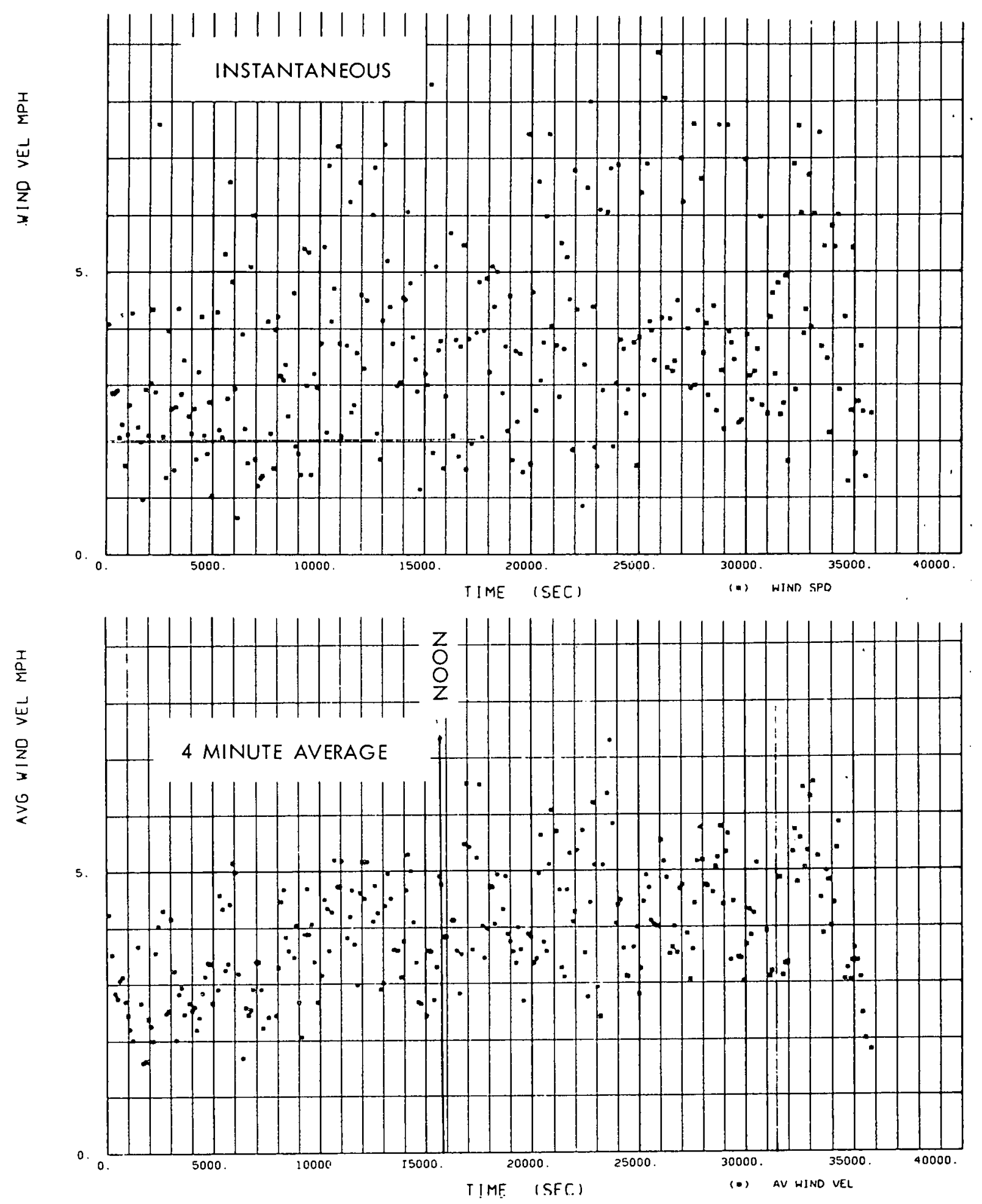

Figure 3-11. Wind Speed Summary 


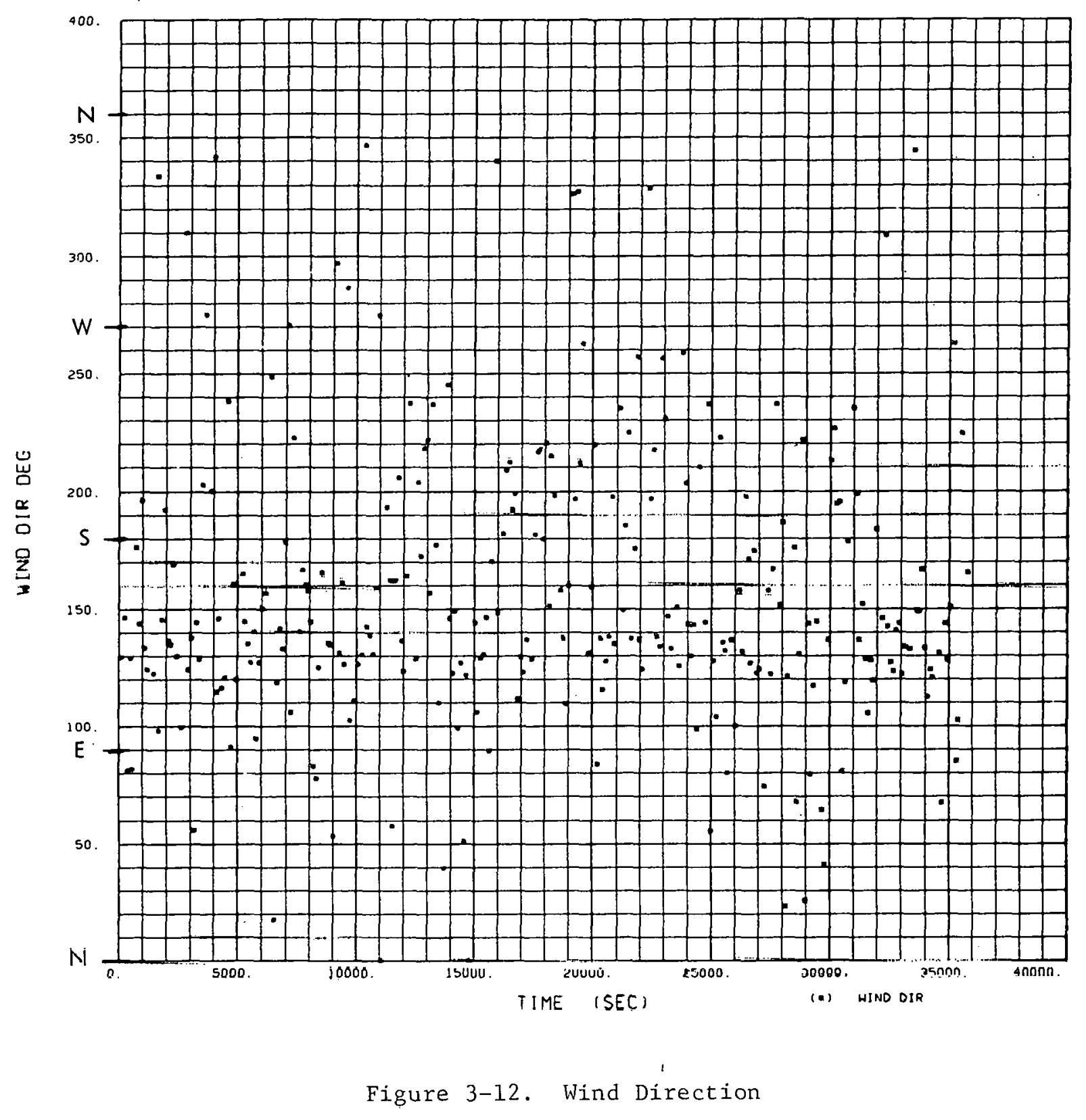



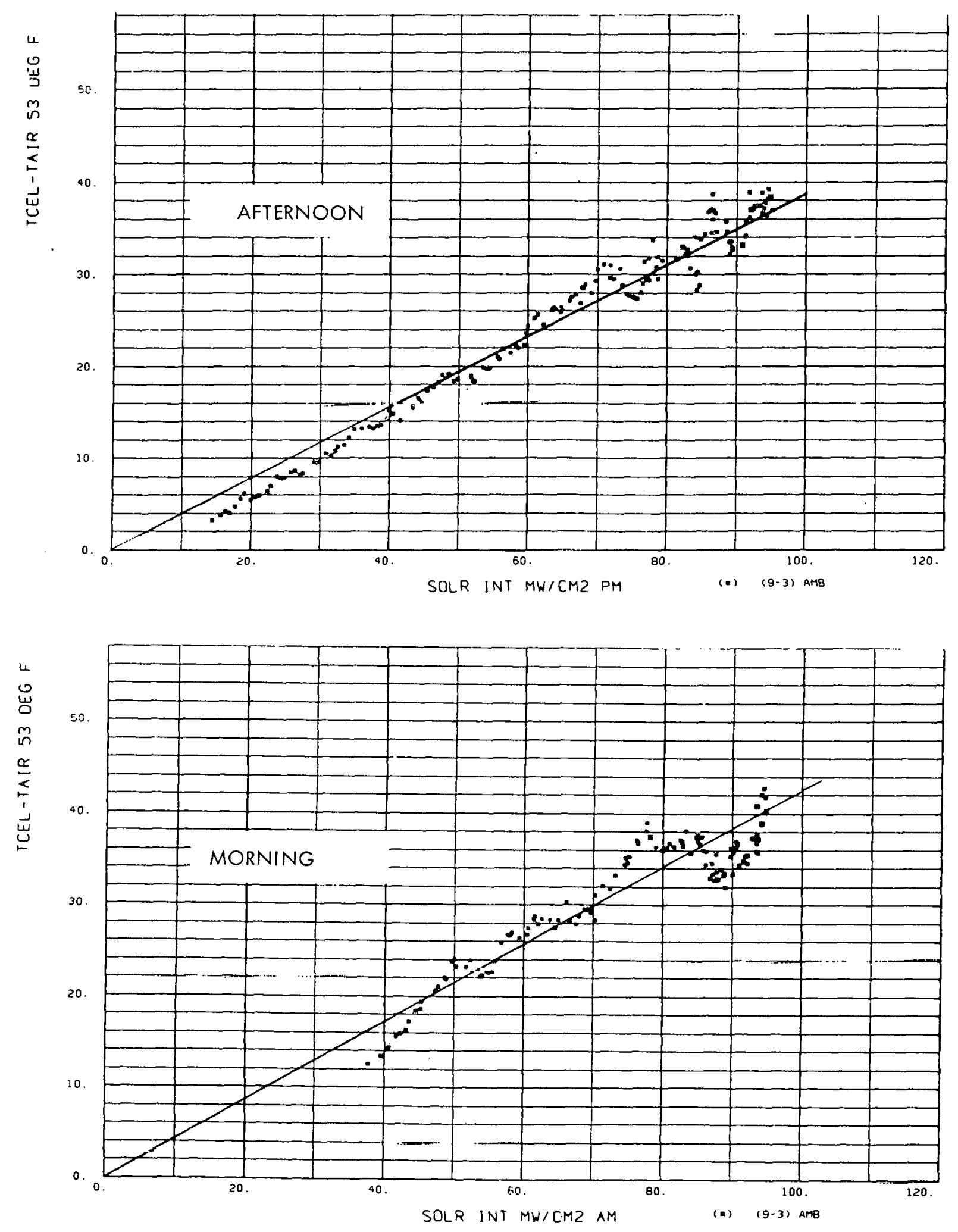

Figure 3-13. ( $\mathrm{T}_{\text {cell }}-\mathrm{T}_{\text {air }}$ ) vs Solar Intensity 


\section{A. NOCT TEST PROCEDURE}

A thermal test procedure to determine the nominal operating cell temperature was developed in the first phase of thermal testing (Reference 1). This procedure has not been changed and is repeated in Appendix A. All of the NOCT characterization tests are performed according to the NOCT test procedure.

NOCT testing is performed in natural sunlight and provides a means of determining accurate and repeatable nominal operating cell temperatures. NOCT tests were recently completed on the Block II modules at the Lewis Research Center (Reference 2). Table 4-1 shows the rosulto of thcoc tcst3 as compared with lle JPL Lesl iesulls fur the same type of modules.

Table 4-1. LeRC and JPL NOCT Test Summary

\begin{tabular}{lll}
\hline $\begin{array}{c}\text { Block II } \\
\text { Module }\end{array}$ & LeRC & NOCT $\left({ }^{\circ} \mathrm{C}\right)$ \\
\hline Solarex & 46.0 & 47.1 \\
Solar Power & 45.0 & 46.0 \\
Spectrolab & 41.0 & 41.1 \\
Sensor Technology & 40.5 & 42.9 \\
\hline
\end{tabular}

B. NOCT OF VENDOR MODULES

Information regarding NOCT testing of the vendor supplied modules measured to date is summarized in Table 4-2. In addition to the llialerlal sumiary of each module, the tabie includes the number of tests made to determine NOCT (the NOCT procedure requires a minimum of two tests) and a tabulation of thermally significant characteristics. Study of Table 4-2 enables some basic conclusions to be drawn about the module thermal design.

1. Air Voids

Air voids within a module should be eliminated. This conclusion was reached by analysis in the first thermal study (Reference 1); modules 5, 14, 19, and 20 experimentally illustrate the higher 
Table 4-2. NOJT Summary

\begin{tabular}{|c|c|c|c|c|c|c|c|c|c|c|c|c|c|c|c|c|}
\hline \multirow[b]{3}{*}{ но. } & \multirow[b]{3}{*}{ Moduie } & \multirow{3}{*}{$\begin{array}{c}\text { Coser } \\
\text { Material }\end{array}$} & \multirow{3}{*}{ Encapsulant } & \multirow{3}{*}{$\begin{array}{c}\text { Electricul } \\
\text { Isolater } \\
\end{array}$} & \multirow{2}{*}{\multicolumn{3}{|c|}{ Subs:rate }} & \multirow{3}{*}{$\begin{array}{c}\text { Front } \\
\text { Inte:cell } \\
\text { Area Color } \\
\end{array}$} & \multirow{3}{*}{$\begin{array}{l}\text { Noct } \\
{ }_{(0 \mathrm{c})}\end{array}$} & \multirow{3}{*}{$\begin{array}{l}\text { No. Tësts } \\
\text { Pcrformed }\end{array}$} & \multicolumn{5}{|c|}{ Therma11y Significant } & \multirow[b]{3}{*}{ Corment } \\
\hline & & & & & & & & & & & Air & $\begin{array}{l}\text { Metal } \\
\text { Sub- }\end{array}$ & & $\begin{array}{c}\text { Non-1 } \\
\text { Subs }\end{array}$ & & \\
\hline & & & & & Ka:er.al & Geonetr.: & & & & & void & & Fins & Opaque & Trans: & \\
\hline 1 & $\frac{\text { Block I }}{\text { Spectrolab }}$ & Class & Sylgard & Dexcillos paper & eluminim & I-Beam & $\mathrm{I}$ & Aluminum & 35.2 & 13 & & $x^{\prime \prime}$ & $x$ & & & Lowest NOCT \\
\hline 2 & Sensor Tech & sylgard & Sylgard & Sylgard & stuminum & Finned & $\mathrm{rmm}$ & Aluminum & 39.0 & 6 & & $\mathrm{x}$ & $x$ & & & \\
\hline 3 & Solarex & silgard & Sylgard & Not required & $=-10 \mathrm{Beard}$ & Sieet & - & Gree. & 47.5 & 10 & & & & $\cdot x$ & & .. \\
\hline 4 & Solar Power & s,ligard & Sylgard & not required & $=-10.80 \times r d$ & sicet & $\longrightarrow$ & Gree: & 48.8 & $\mathrm{~s}$ & & & & $\mathrm{x}$ & & \\
\hline 5 & H-7 & Plexi-glas & Mir . & not required & $\because$ Iexi-glas & simeet & - & Transparent & 59.6 & 5 & $x$ & & & & $x$ & Highest NOCT \\
\hline & Block II and MIni & & & & & & & & & & & & & & & \\
\hline$\stackrel{6}{7}$ & $\frac{\text { Spectrolab }}{(\operatorname{Min} 1)}$ & $\begin{array}{l}\text { Glass } \\
\text { Glass }\end{array}$ & $\begin{array}{l}\text { PVB } \\
\text { PVB }\end{array}$ & $\begin{array}{l}\text { not required } \\
\text { slut required }\end{array}$ & $\begin{array}{l}\text { =olyester } \\
\text { rolyester }\end{array}$ & $\begin{array}{l}\text { Sacet } \\
\text { Silieet }\end{array}$ & $\longmapsto$ & $\begin{array}{l}\text { Transparent } \\
\text { Transparent }\end{array}$ & $\begin{array}{l}41.1 \\
(43.11\end{array}$ & s & & & & & $\begin{array}{l}x \\
x\end{array}$ & \\
\hline $\begin{array}{l}8 \\
9\end{array}$ & $\begin{array}{c}\text { Sensor rech } \\
\text { (Min1) }\end{array}$ & $\begin{array}{l}\text { RTV nils } \\
\text { RTV h15 }\end{array}$ & $\begin{array}{l}\text { RTV } 115 \\
\text { RTV } F 15\end{array}$ & $\begin{array}{l}\text { PUC/Fiberglas } \\
\text { PWe/rinerglios }\end{array}$ & 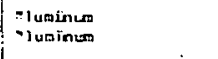 & $\lim$ & $\stackrel{\longrightarrow}{\longrightarrow}$ & $\begin{array}{l}\text { Aluminum } \\
\text { Al umisioum }\end{array}$ & $\left|\begin{array}{l}42.9 \\
64.26\end{array}\right|$ & $\begin{array}{r}8 \\
13\end{array}$ & & $\underset{x}{x}$ & & & & \\
\hline $\begin{array}{l}10 \\
\vdots 1\end{array}$ & 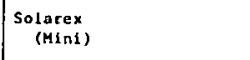 & $\begin{array}{l}\mathrm{RTV} \\
\mathrm{RIV}\end{array}$ & $\begin{array}{l}\mathrm{RTV} \\
\mathrm{RTV}\end{array}$ & $\begin{array}{l}\text { not required } \\
\text { Jot required }\end{array}$ & $\begin{array}{l}\text { Folyescer } \cdots \\
\text { Folyescer }\end{array}$ & $\mid \begin{array}{l}\text { Sicet } \\
\text { sineet }\end{array}$ & $\stackrel{r}{\longrightarrow}$ & $\begin{array}{l}\operatorname{Pan}_{\mathrm{an}} \\
\mathrm{ran}\end{array}$ & $\left|\begin{array}{l}47.1 \\
(46.2)\end{array}\right|$ & $\begin{array}{r}8 \\
12\end{array}$ & $\therefore$ & & & $\begin{array}{l}x \\
x\end{array}$ & & \\
\hline$\frac{12}{13}$ & $\begin{array}{l}\text { Solar Pover } \\
\text { (Mini) }\end{array}$ & $\begin{array}{l}\text { Sillcong Coat:nn } \\
\text { silicong coat ing }\end{array}$ & $\begin{array}{l}\text { RTV } \\
\text { RTV }\end{array}$ & $\begin{array}{l}\text { Jot required } \\
\text { Jot required }\end{array}$ & $\begin{array}{l}\text { olyescer" } \\
\text { iolyester }\end{array}$ & 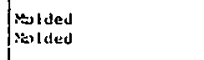 & $\pi$ & $\begin{array}{l}\text { Whice } \\
\text { Wlice }\end{array}$ & $\left|\begin{array}{c}46.0 \\
(4.4 .41\end{array}\right|$ & $\frac{2}{12}$ & & & & $\begin{array}{l}x \\
x\end{array}$ & & \\
\hline & RBD & : & & & . & & & & & & & & & & & \\
\hline 14 & Eos (Xerox) & $\because$ Class & RTV fis & circuit Bozerd & - Iumings & iscruded & $\neg$ & Blue & 40.3 & 7 & $\mathrm{x}$ & $\mathrm{x}$ & & & & \\
\hline :s & Lockheed & iGlass & Sylgard & Fot required & i =iliume تunt ink & sicect & $\longmapsto$ & Transparent & 42.4 & 13 & & & & & $\mathrm{x}$ & \\
\hline$: 6$ & Motnrola & 'Glass & Silicune le! & Polyimid/Class & tairless & inn & $\longmapsto$ & Urange & Si. 3 & 10 & & $x$ & & & & Local vold Beneath Cell suspected \\
\hline$\therefore$ & Sensor Tech Eigh & iRTV 615 & RTV $t: 15$ & RTV ńls & - longming & fran & ـ & Muni num & 44.5 & $15:$ & & $x$ & & & . & \\
\hline$: 8$ & ocLi & Glass & RTV & intar & =lum incm & theet & $\longmapsto$ & Muminum & 45.5 & s & & $x$ & & . & & \\
\hline$\therefore 9$ & Solar Tech 1ric. & class & Neopcene & :eoprene & Punimm & Bix & $\square$ & cray & 31.3 & s & $\mathrm{x}$ & $x$ & & & & \\
\hline 20 & Arco Solar Ixc. & class & s"y & Oot required & -ylar & aicet & - & Transparent & 54.9 & 7 & $x$ & & & & $\mathrm{x}$ & $\begin{array}{l}\text { Box Support Creates void Beneath } \\
\text { Substrate }\end{array}$ \\
\hline 21 & $\begin{array}{l}\text { Solarex (Bik 111) } \\
\text { JPL Modiried }\end{array}$ & Rrv & RTV & :ot required & folyester & Shcet & $\longmapsto$ & ran & 40.5 & is & & & & $x$ & & Junstrace \\
\hline 22 & Solarex 1 (N. 3) & splgard & sylgerd & Slot requi red & "Flatee' $1 ;-1.1$ buard & Sheet & - & Green & $\$ 5.1$ & 10 & & & & $x$ & & 1/2" Flake board Bonded to Backside \\
\hline$=3$ & Solar Pouer 1 (No. G) & sylgard & siytgrod & c-10) Board & "Munirua" & Sheet & 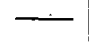 & Green & 50.6 & 8 & & $x$ & & & & 1'y" Aluminum bonded to Backside \\
\hline 24 & Sensor Tech 1 & sylgard & Sylgard & sylgard & :Huamimam & "Silect" & — & Muninum & 41.7 & 3 & & $\mathrm{x}$ & & & & Fins Remuved \\
\hline is & $\cos$ (Xerox) (No. 14) & Glass & RTV $5: 15$ & circuit Board & : Aluminum & "Voidless" lixtrudes: & -2 & Blue & 45.6. & 4 & & $x$ & & & & Void Bencutll ciell Filled \\
\hline 26 & H-7 (No. S) & Plexi-gl=s & RTV 0.15 & Zlot required & Blexi-gias & sheere & - & Transparent & 54.1 & s & & & & & $\mathrm{x}$ & vord between cell and Cover filled \\
\hline 27 & M-7 (No. 26) & Plexi-glss & RTV 5.15 & Sot required & "prairtod" exi-glas & Sileet & - & Whit te & 57.2 & 10 & & & & $x$ & & Backside painted thite, void filled \\
\hline ¿8 & Spectrolab MInI (No. ") & class & PVB & \#ot required & Falnced Polrester & Saces & $\longrightarrow$ & Mlice & 44.6 & 8 & & & & $x$ & & Backside Painted inite \\
\hline 29 & Solor Pover I (No. 23i & sylgard & Sylgard & C-10 Board & 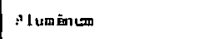 & Soleet & - & creen & 49.6 & 10 & & $\mathrm{x}$ & & $\mathrm{x}$ & & Muminum Painted thite \\
\hline
\end{tabular}


temperatures due to air voids. Module 5, which has an air void between the front cover and the cell, has the highest NOCT measured $\left(59.6^{\circ} \mathrm{C}\right)$. Module 14 has only a partial void beneath the cell and the metal substrate, and a significant part of the cell is mounted directly above the metal substrate. As a result, the void in this instance is not a dominating thermal effect. Elimination of the void by injecting RTV 615 reduced its NOCT only from $46.3^{\circ} \mathrm{C}$ to $45.6^{\circ} \mathrm{C}$.

The air void in modules 19 and 20 are not totally enclosed. In each case the void is created by a box, open at both ends, which is the support structure and/or a combination of support and substrate. Except for the box, module 20 is thermally very similar to module 15 . Module 15 (no box) is $11^{\circ} \mathrm{C}$ cooler than module 20 , and gives an indication of the improvement in operating temperature that could be obtained with a totally open configuration. (An $11^{\circ} \mathrm{C}$ reduction in module temperature translates into a 5\% improvement in power.)

If the void thickness is greater than approximately $1.2 \mathrm{~cm}$, heat transfer across the void by free convection is probable. If free convection is occuring, filling the void with RTV will not reduce the temperature as much as would occur if conduction through the air was the main heat transfer mode. To illustrate, the large void in module 5 was filled with RTV 615, which has a thermal conductivity 6.5 times greater than that of air. The decrease in NOCT was only $5^{\circ} \mathrm{C}$, from $59.6^{\circ} \mathrm{C}$ to $54.1^{\circ} \mathrm{C}$. If conduction through the air had been the main mode of heat transfer, a reduction in NOCT of $10^{\circ} \mathrm{C}$ to $15^{\circ} \mathrm{C}$ would have been expected, since after filling, the module is just a thicker version of module 6 , whose NOCT is $41.1^{\circ} \mathrm{C}$.

Voids should be designed out of the module. Filling the void as an afterthought will probably not be cost effective due to the cost of the filler material and labor.

\section{Fins}

Both modules 1 and 2 have a finned metal substrate and have the lowest NOCTs. The fins were machined from module 2 and the NOCT increased $2.7^{\circ} \mathrm{C}$ to $41.5^{\circ} \mathrm{C}$. (This NOCT is not very different from that of modulc 8 which ic thermaly similar to modıle 2 hut has no fins.) Therefore, the fins probably increased the power $1 \%$ to $2 \%\left(0.5 \%\right.$ per $\left.{ }^{\circ} \mathrm{C}\right)$.

The average cost of the Block I modules was approximately $\$ 20$ per watt. Module 2 has an output of about 5 wats. Therefore, the fins contributed 0.1 watts to this total. To be cost effective the fins would have to cost less than $\$ 2$ per module $(20 \times 0.1)$. While possibly cost effective for the Block I mudules, it is obviously not going to be cost effective at the 1986 cost goal of $\$ 0.50$ per watt. Since the Block I purchase, there has been only one module design with fins, which is probably the best indication that fins may not be cost effective even at today's prices. 


\section{Transparent vs Opaque Substrates}

Modules 6, 7, and 15 have transparent substrates, and their NOCTs are about the same as otherwise thermally equivalent modules (modules 8 and 9) with metal substrates (no fins). In the first study (Reference 1) it was cautioned that the transparent module in a residential roof installation would run warmer due to heating of the air void (very similar to that of module 20) created between the roof and the module.

Recently, tests at JPL and by G.E. have demonstrated that a white reflective intercell area increases the power output of the module significantly. A diffuse white paint on the back of module 7 increased the power output by $8 \%$ and increased the NOCT by $1.5^{\circ} \mathrm{C}$, from $43.1^{\circ} \mathrm{C}$ to $44.6^{\circ} \mathrm{C}$. Therefore, the net power increase is at least $7 \%$. This is another reason for not using a transparent substrate. White polyester is used to create a reflective intercell area in modules 12 and 13. The use of white tedlar or porcelain has also been suggested as a means of ohtaining the solar rellectlve flitish. Compared to the transparent substrate, thermal performance is negligibly different for a white substrate, but the demonstrated increase in electrical performance makes the white substrate the preferred design.

4. Metal vs Nonmetal Substrates

Depending upon the nonmetal material used, the thermal advantage of the metal substrate can be reduced to a negligible consideration. A comparison of the NOCT for modules 8,9 , and 18 (metal substrate) with modules 12 and 13 (white polyester) illustratcs that the metal substrate (aluminum) is at most $3^{\circ} \mathrm{C}$ conler. Moreover; after painting the back side of module 7 (PVB substrate) the NOCT was only $0.2^{\circ} \mathrm{C}$ warmer than that of module 9. Also, bonding (ECOBOND 57C) a $0.05 \mathrm{~cm}$ (1./8 inch) aluminum sheet (white exterior) to the back of module 4 (G10 board substrate) increased the NOCl from $48.8^{\circ} \mathrm{C}$ to $49.6^{\circ} \mathrm{C}$.

None of these differences is significant enough to make the metal substrate thermally preferred over a nonmetal substrate. If, as predicted, material cost favors less thermally conductive steel over aluminum, the thermal rating of the module with nonmetal substrate could be the same to slightly better than that of the module with steel substrate.

\section{High Efticiency Modules}

The use of inexpensive rectangular cells will result in high efficiency modules. The effect on NOCT of increasing the nesting efficiency from approximately $75 \%$ (circular cells) to $100 \%$ (square, rectangular, hexagonal) is obtained by comparing the NOCT of modules 8 and 17. The construction is essentially identical, except 
that module 8 uses circular cells and module 17 uses hexagonal cells to obtain the high nesting efficiency. A $1.6^{\circ} \mathrm{C}$ increase in NOCT, or less than a $1 \%$ decrease in power is indicated with elimination of most of the non-cell area.

\section{NOCT OF RESIDENTIAL ROOF INSTALLATIONS}

A $1.22 \mathrm{~m} \times 1.22 \mathrm{~m}$ segment of a photovoltaic residential roof installation was simulated. The array consisted of three identical modules, and the NOCT of the center module (module 12) was determined. Initially, the mounting technique approximated that proposed by Lincoln Laboratory for residential demonstration purposes. In the Lincoln Lab configuration, the modules are suspended about $7.6 \mathrm{~cm}$ from the roof by supports which attach at the top and bottom edges of the module. Air flow beneath the modules is discouraged by this design, and only the modulec mountad alnng the east and west edges will benefit from sporadic wind-induced air movement beneath the modules. Later, the attachment technique was changed to simulate hard mounting to the roof in order to approximate thermally a shingle module configuration. Figure 4-1 illustrates the hard mounted configuration with an insulated roof. Table 4-3 summarizes the results.

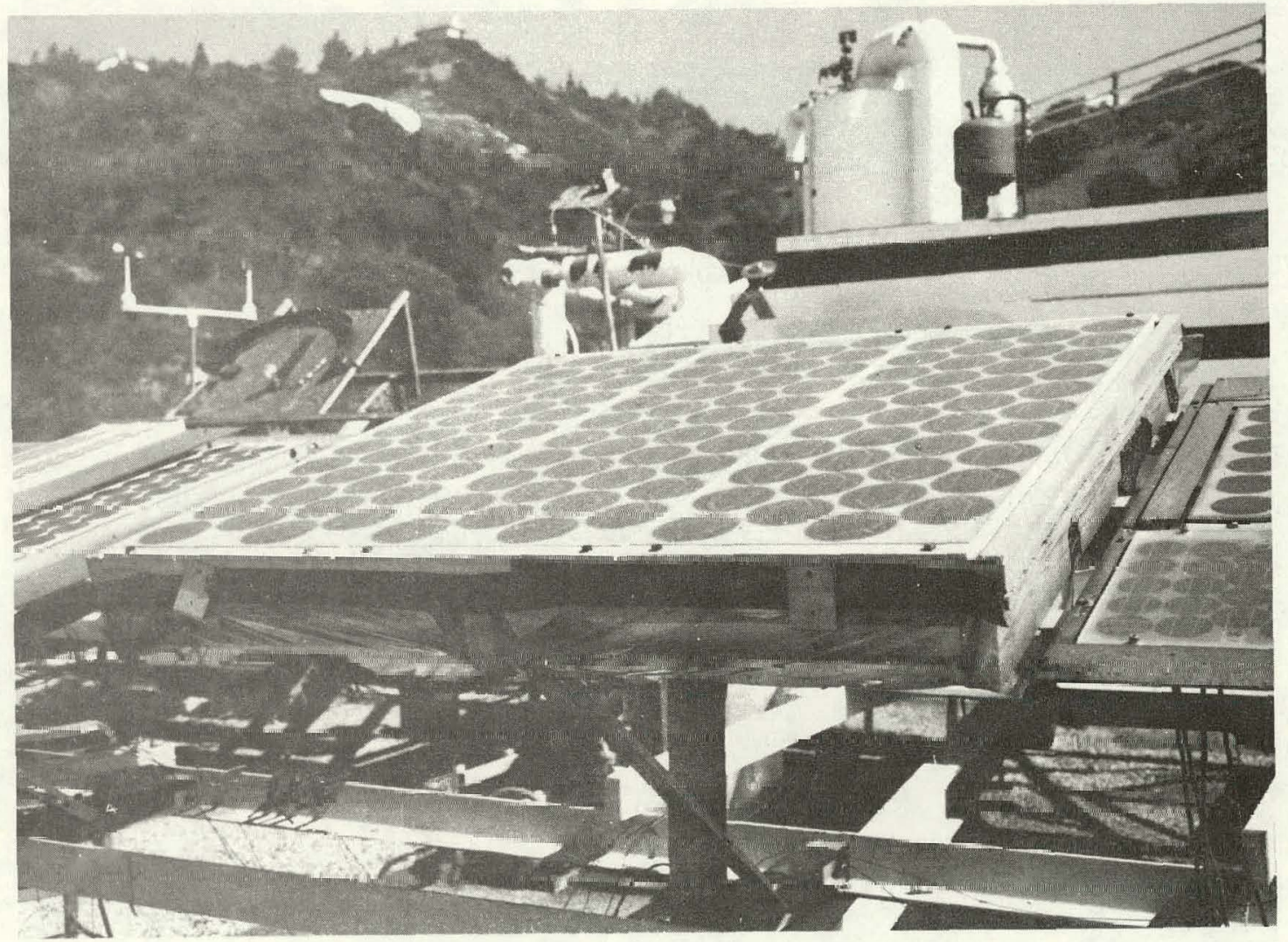

Figure 4-1. Roof Mount Simulation 
Table 4-3. NOCT Summary for a Residential Roof Installation

\begin{tabular}{|c|c|c|c|}
\hline Case No. & Configuration & $\begin{array}{l}\text { NOCT } \\
\left({ }^{\circ} \mathrm{C}\right)\end{array}$ & $\begin{array}{l}\triangle \mathrm{NOCT}^{*} \\
\left({ }^{\circ} \mathrm{C}\right)\end{array}$ \\
\hline \multicolumn{4}{|c|}{ Lincoln Laboratory Mounting } \\
\hline 1 & $\begin{array}{l}\text { Module at center of roof (No flow } \\
\text { beneath module) }\end{array}$ & 55.5 & 9.5 \\
\hline \multirow[t]{2}{*}{2} & $\begin{array}{l}\text { Module at east/west edge of roof } \\
\text { (Permits east-west air flow) }\end{array}$ & 49.9 & 3.9 \\
\hline & \multicolumn{3}{|l|}{$\underline{\text { Modified Configuration }}$} \\
\hline 3 & $\begin{array}{l}\text { Sides closed, top/bottom edges open } \\
\text { (Permits flow bottom to top) }\end{array}$ & 50.8 & 4.8 \\
\hline \multirow[t]{2}{*}{4} & $\begin{array}{l}\text { All edges open (Permits flow in all } \\
\text { directions) }\end{array}$ & 49.4 & 3.4 \\
\hline & \multicolumn{3}{|l|}{$\begin{array}{l}\text { Shingle Type Mounting } \\
\text { (Hard mounted to roof) }\end{array}$} \\
\hline 5 & Roof uninsulated & 58.0 & 12.0 \\
\hline 6 & Roof insulated & 61.5 & 15.5 \\
\hline
\end{tabular}

* NOCT of this module is $46^{\circ} \mathrm{C}$ for the normal field installation.

1. Lincoln Laboratory Configuration

With no air flow benedh the modules (Lase 1 ), as would be typical of the intermost-mounted modules, the NOCT is $9.5^{\circ} \mathrm{C}$ warmer $\left(55.5^{\circ} \mathrm{C}\right.$ compared to $46.0^{\circ} \mathrm{C}$ ) than the NOCT for the same module mounted in the normal field installation. Modules along the east or west edge (Case 2) would be $3.9^{\circ} \mathrm{C}$ warmer, because some air flnw is possible through the open sides. If the modules were attached along the sides rather than along the top and bottom edges (Case 3 ), the module is $4.8^{\circ} \mathrm{C}$ warmer. If the module was suspended from the roof by legs rather than rails (Case 4 ), the module is $3.4^{\circ} \mathrm{C}$ warmer.

This test series illustrates that higher operating temperatures wil1 orrur fur residential root installalions, and the decrease in electrical performance will be $2 \%$ to $5 \%$ in the worst case. A mounting technique permitting more air flow could cut this penalty in half. However, the module support structure is also utilized to support ladders (or the equivalent), which enable the initial installation of 
the modules as well as future servicing to be carried out with no damage to the modules or the existing roof. A mounting technique which assures this protection is well worth a $1 \%$ to $2-1 / 2 \%$ decrease in electrical performance.

\section{Shingle Simulated Mounting}

It is not surprising that hard mounting the module to roof increases the NOCT further. For an uninsulated roof (Case 5), the NOCT is $12^{\circ} \mathrm{C}\left(58.0^{\circ} \mathrm{C}\right.$ compared to $\left.46^{\circ} \mathrm{C}\right)$ warmer than the normal open-back field installation. If the roof is insulated on the attic side (Case 6$)$, the NOCT is $15.5^{\circ} \mathrm{C}$ warmer $\left(61.5^{\circ} \mathrm{C}\right)$.

Hard mounting this particular module does create an air-void between the substrate dul the roof. A shingle module should not and probably would not be designed in this manner. It is estimated that the temperature increase would be $4^{\circ} \mathrm{C}$ less if there were no air void. This estimate is based upon bonding "flake board" ( $1.9 \mathrm{~cm}$ thick) to the back of module 3 ; the NOCT increased $7.6^{\circ} \mathrm{C}\left(47.5^{\circ} \mathrm{C}\right.$ to $\left.55.1^{\circ} \mathrm{C}\right)$. Without the voids the temperature rise would be similar to that of a module located in the center of the roof (Case 1) for the Lincoln Laboratory Configuration.

A possible conclusion from these tests is that unless the module is suspended from the roof so that air can flow in all directions beneath the module (Case 4), it may be better to hard mount the module, trading the slight decrease in performance for the saving in structure cost. Moreover, the module that is integrated into the roof installation may be better adapted for repair in the event of a leak. Repairing a leak located beneath a module mounted in the Case 4 configuration is not likely to be attempted by the average home owner, and the repair could prove to be involved and expensive. In summary, the improvement in thermal performance of modules mounted in this manner (off of the roof) may not justify the additional initial and long term cost.

\section{NOCT OF DIRTY MODULES}

Figures 4-2 and 4-3 show the effect on NOCT of dirt accumulation for modules with non-glass and glass front surfaces, respectively. Measurements for modules with non-glass surfaces were made at a tilt angle of $13^{\circ}$ during June and July. Tilt angles of the glass-surface modules began at $13^{\circ}$ and were at $18^{\circ}$ by the end of the test period, which nccurred at the middle of August. These low tilt angles encourage maximum dirt accumulation will respect to specific test site. The NOCT for modules with the non-glass front surfaces increased $1.3^{\circ} \mathrm{C}$ to $2.2^{\circ} \mathrm{C}$ during the first week and remained constant during the next three weeks. The NOCT of modules with glass front surfaces increased less than $0.5^{\circ} \mathrm{C}$ during the three week period of dirt accumulation. Although greater for non-glass than for glass surfaces, the effect of dirt accumulation on NOCT is not significant. 

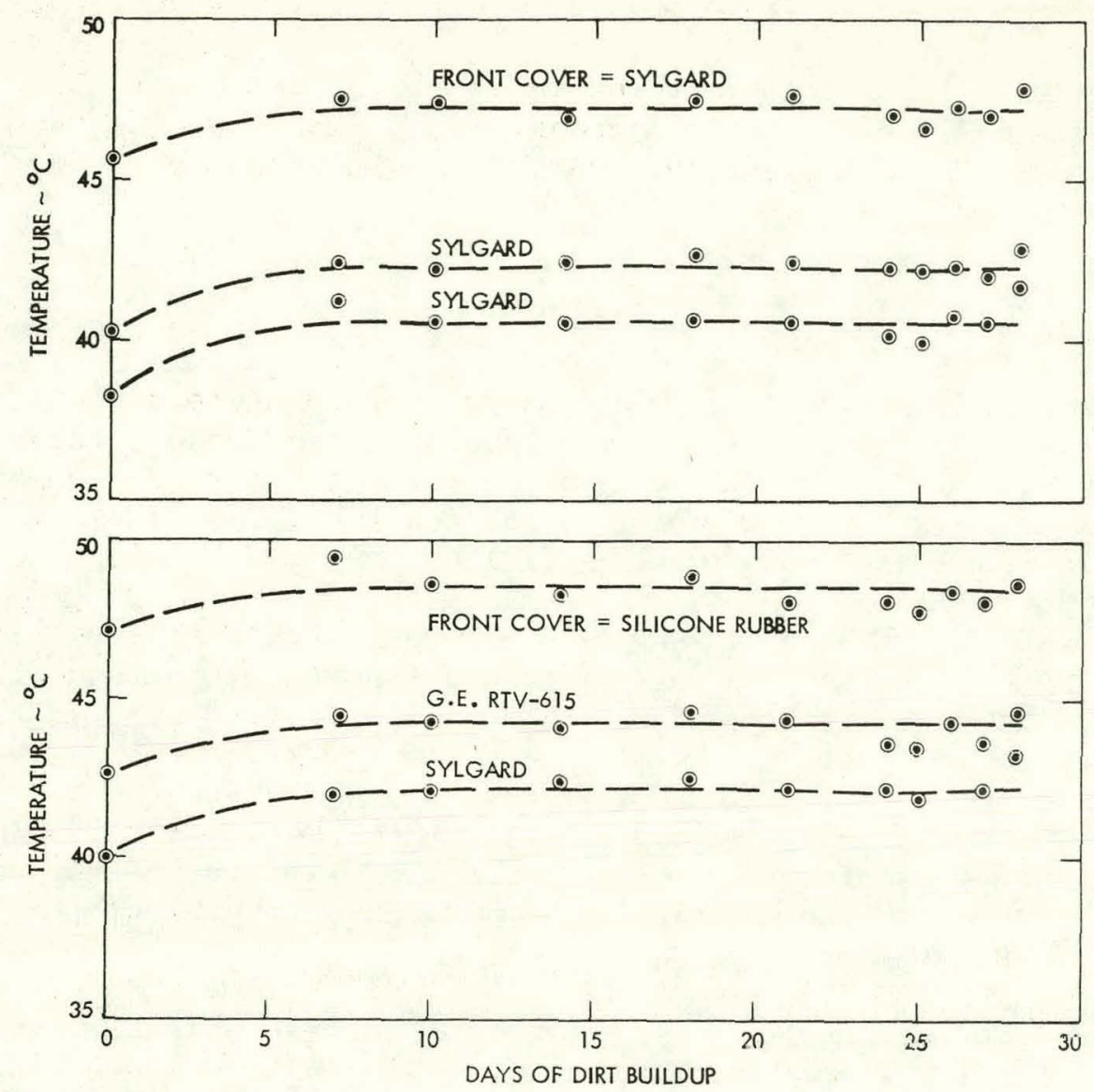

Figure 4-2. Effect of Dirt Accumulation on NOCT (Non-Glass Front Surfaces)

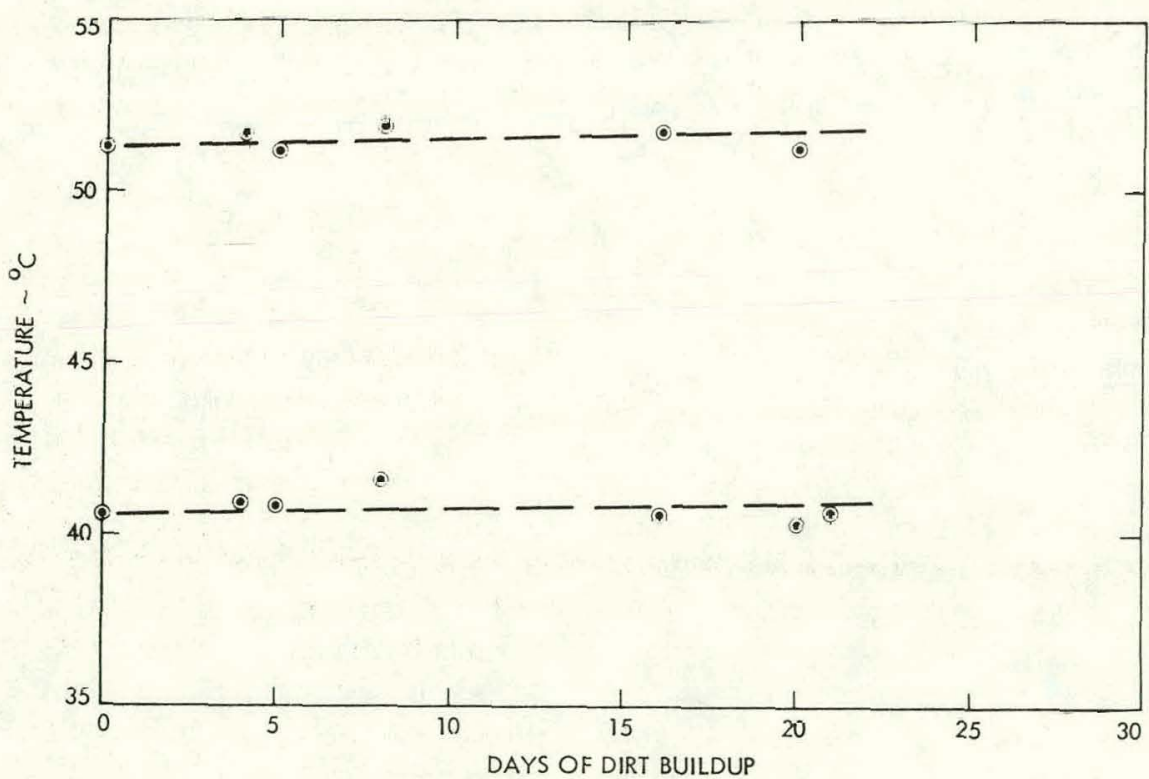

Figure 4-3. Effect of Dirt Accumulation on NOCT (Glass Front Surfaces) 
The measured decrease in electrical output which occurs as a result of dirt accumulation is discussed in section V. Because of the effect of dirt accumulation on electrical output as well as on maintenance costs, ease of cleaning is a factor which may be of some significance. In the standard NOCT test, the modules are cleaned before each test. It has been observed that it takes more water, more towels, and more "elbow grease" to clean the non-glass front surfaces. This suggests that the cleaning machine for non-glass front surface modules may cost more, use more materials, and take longer to do the job than an equivalent machine designed for washing modules with glass front surfaces. In short, the cleaning cost may be significantly higher for non-glass modules.

\section{E. NOCT AND MAXIMUM POWER}

Normally NOCT is performed with a zero puwer output (open circuit conditions) in an effort to reduce the complexity of the test. Performance of a test during which maximum power was continuously removed from the module resulted in a reduction in NOCT of $2.9^{\circ} \mathrm{C}$. This reduction offsets the temperature rise due to dirt accumulation, an effect which is not accounted for in the determination of NOCT.

F. NOCT IN A SOLAR DOME

Two solar dome concepts being studied by Boeing are illustrated in Figure 4-4. The weathered polyester film encloses the arrays and thereby eliminates the requirement for weather-proof encapsulation of the cells, screens UV, and enables a low-cost array structure. The resulting cost saving must be balanced against the significant reduction in power due to the high operating temperatures characteristic of the green house.

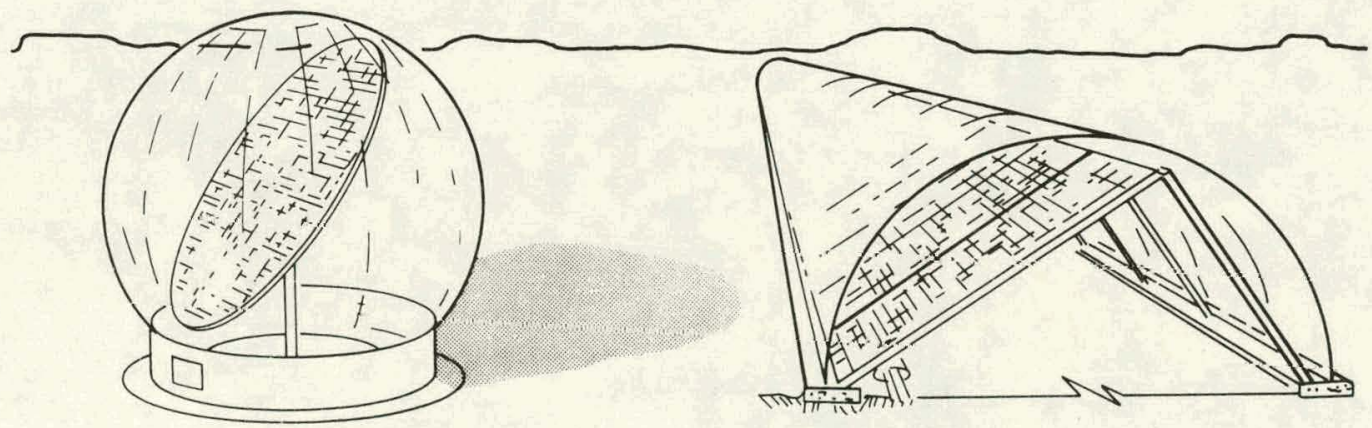

Figure 4-4. Solar Dome Concepts 
Figure $4-5$ is the test setup used to evaluate the NOCT of a module in a solar dome. A Spectrolab Block II module was used for the measurements, and the polyester film is identical to that proposed by Boeing. The procedure was carried out first with white and later with black floor.

The first set of data was obtained with the plywood floor painted white; the black floor was created using a layer of black plastic. Table 4-4 is a summary of the NOCT measurements. The dome environment increases the NOCT of the module (normally $41.1^{\circ} \mathrm{C}$ ) $28.2^{\circ} \mathrm{C}$ and $37.1^{\circ} \mathrm{C}$ for the white floor and black floor, respectively. A corresponding power reduction of $14.1 \%$ and $18.6 \%$ would be expected.

The white paint also reflects more energy onto the cells. Therefore, the improvement in performance is actually greater than $4.5 \%$, as indicated by the NoCT difference. In a real application, the module should be positioned back (north) in the cylindrical enclosure as much as possible to maximize the reflective floor area in front of the module.

As Boeing has found, an active cooling system for a power station configuration is not economically feasible. However, the light weight of this system makes it well suited for roof installations (apartments, factories, etc.), and the high temperatures suggest the combination of photovoltaic with space and/or hot water heating. Together the two systems could prove to be economically viable.

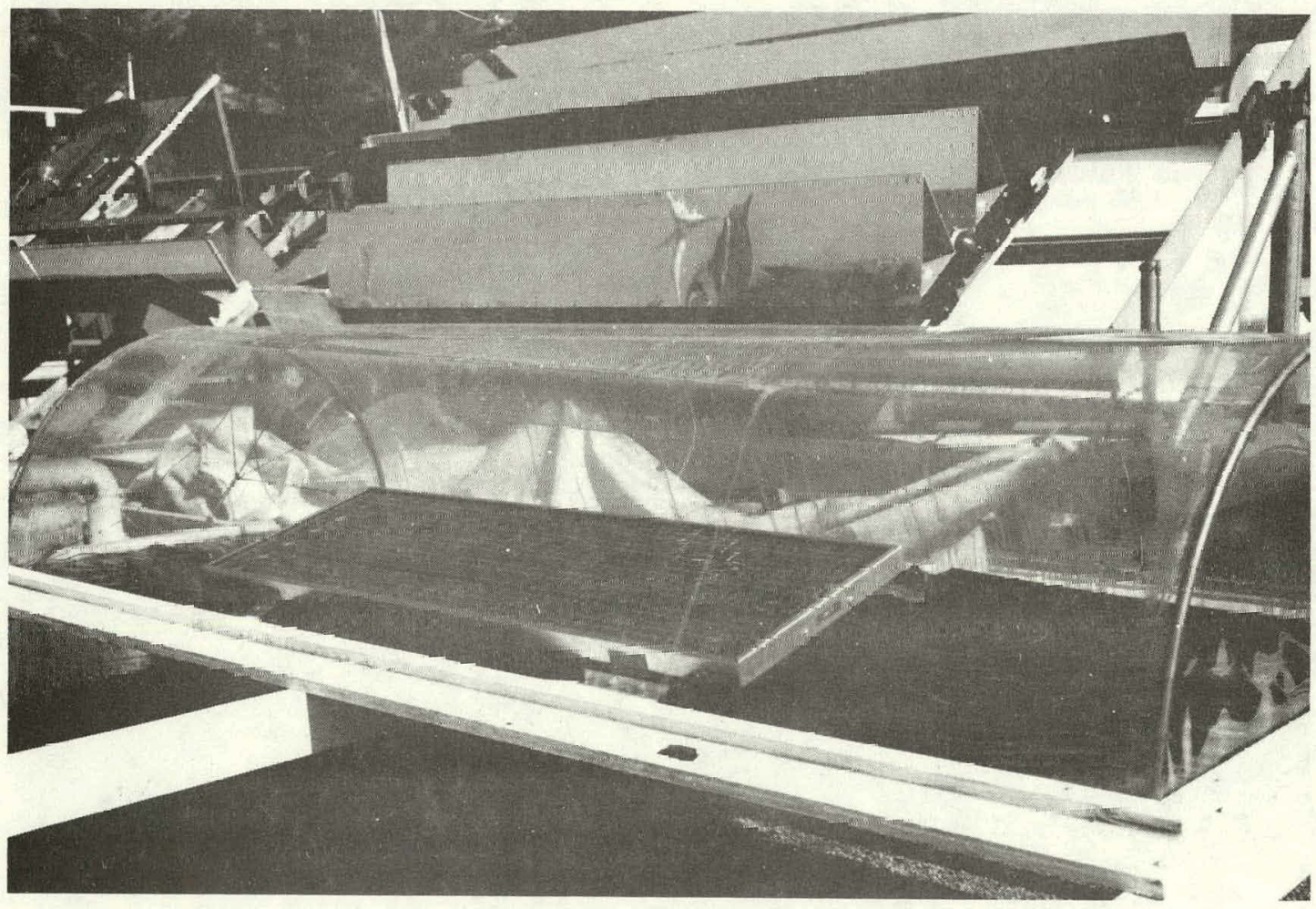

Figure 4-5. Dome Test Setup 
Table 4-4. Solar Dome NOCT Summary

\begin{tabular}{|c|c|c|c|}
\hline & & $\mathrm{NOCT} \sim{ }^{\circ} \mathrm{C}$ & \\
\hline Test Date & Morning & & Afternoon \\
\hline White Floor & & & \\
\hline $4 / 17 / 78$ & 65.0 & & 73.0 \\
\hline $4 / 18 / 78$ & 65.0 & & 71.7 \\
\hline $4 / 19 / 78$ & 66.0 & & 73.1 \\
\hline $5 / 2 / 78$ & 68.0 & & 72.4 \\
\hline Average & 66.0 & & 72.6 \\
\hline Daily Average & & 69.3 & \\
\hline \multicolumn{4}{|l|}{ Black Floor } \\
\hline $5 / 12 / 78$ & 74.3 & & 81.6 \\
\hline $5 / 16 / 78$ & .74 .9 & & 82.0 \\
\hline $5 / 19 / 78$ & 74.9 & & 81.3 \\
\hline Average & 74.7 & & 81.6 \\
\hline Daily Average & & 78.2 & \\
\hline
\end{tabular}




\section{SECTION $V$}

OTHER TESTS

\section{A. WATER COOLED MODULE}

This study was prompted because some applications involve the movement of a large amount of water. For example, the irrigation project in Nebraska pumps 60,000 gallons per hour or 1,542 gallons per hour per square foot of module area. While this flow rate is adequate, much larger flow rates are possible with a simple gravity feed configuration, such as a common trough feeding water into the top of tubes attached or built into the back of the modules, and discharging it into a holding pond or into the supply system. A larger flow rate would improve the performance slightly.

In the test selup water was circulated through two copper tubes bonded to the backside of a Block.I Spectrolab module. This module has two rows of cells mounted in a staggered pattern on an aluminum I-beam. As illustrated in Figure 5-1, the copper tubes were bonded on either side of the I-beam beneath the cells with a thermally conductive adhesive (Eccobond 57C). The inlet water temperature was maintained constant during the test. Maximum power was continuously drawn from the module. Figure 5-1 presents temperatures of the module as measured

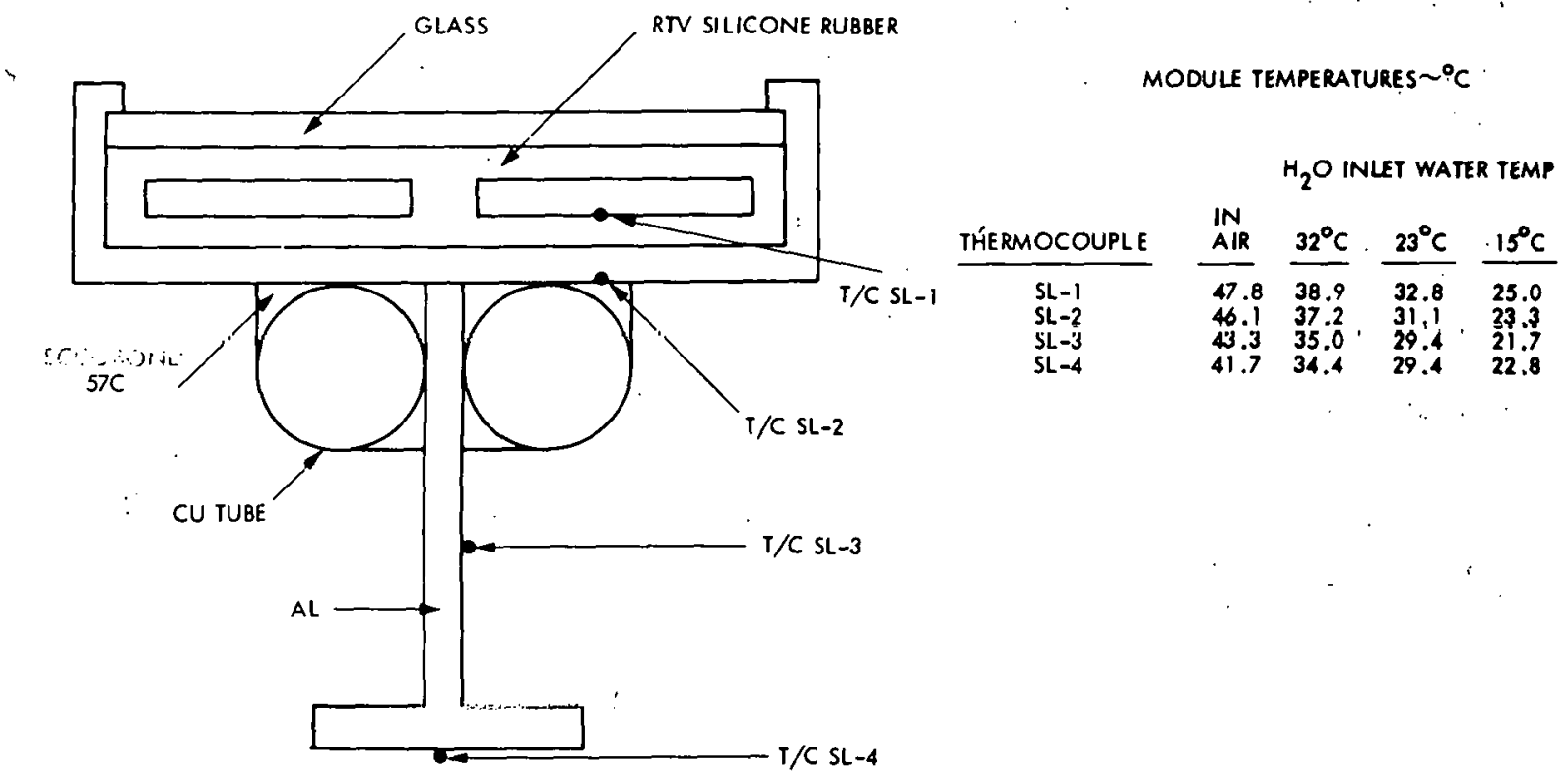

Figure 5-1. Module Temperature Profile at Noon (Insolation $=95 \pm 2 \mathrm{~mW} / \mathrm{cm}^{2}$ ) 
at noon. With water cooling the gradient through the module is cut almost in half, and the cell is about $3^{\circ} \mathrm{C}$ warmer than the local water temperature. "Reversing the flow (bottom to top) had no effect on the temperature profile, and there was no measurable change in $P_{\max }$ when the flow was increased by a factor of five.

mined by:

The average electrical efficiency of the module $\left(n_{\varepsilon}\right)$ was deter-

$$
\eta_{\varepsilon}=\frac{\int P_{\max } \mathrm{d} \theta}{\int \mathrm{LAd} \theta}
$$

where:

$$
\begin{aligned}
& \theta \quad=\text { time } \\
& \mathrm{L} \quad=\text { total intensity } \\
& \mathrm{A} \quad=\text { module area } \\
& \mathrm{P}_{\max }=\text { maximum power }
\end{aligned}
$$

The $n_{\varepsilon}$ values for the tests are presented in Figure 5-2. Also shown is the $n_{\varepsilon}$ without water cooling and the expected $n_{\varepsilon}$ for other air temperatures assuming the calculated change in $\eta_{\varepsilon}$ of $0.038 \%$ per ${ }^{\circ} \mathrm{C}$ change in average air temperature. On a hot summer day $\left(35^{\circ} \mathrm{C}\right.$ average air temperature), $n_{\varepsilon}$ would be about $5.2 \%$ for the normal field installation with air cooling only. With $23^{\circ} \mathrm{C}\left(75^{\circ} \mathrm{F}\right)$ and $15^{\circ} \mathrm{C}\left(60^{\circ} \mathrm{F}\right)$ watcr, power generation on this same hot day could be increased $16.0 \%$ $\left(n_{\varepsilon}=6.03 \%\right)$ and $20.8 \%\left(n_{\varepsilon}=6.28 \%\right)$, respectively. Even with $32.2^{\circ} \mathrm{C}$ $\left(90^{\circ} \mathrm{F}\right.$ ) water, power generation would improve $11.0 \%$ (5.77\% compared to $5.2 \%$ ) on the summer type day.

If it is not already, available, pumping power will consume most or all of the improvement in power production. Therefore, while each application must be treated separately, conling with water is not expected to be cost effective unless the application already involves the pumping of water or unless a gravity water feed system is possible. Assuming either of the latter conditions exists, the one-time plumbing cost will not be a significant cost factor; the cost of a module should not be increased significantly by building into the module substrate the cooling channels or the provision for bonding/inserting copper cooling tubes, which cuuld be optional. 


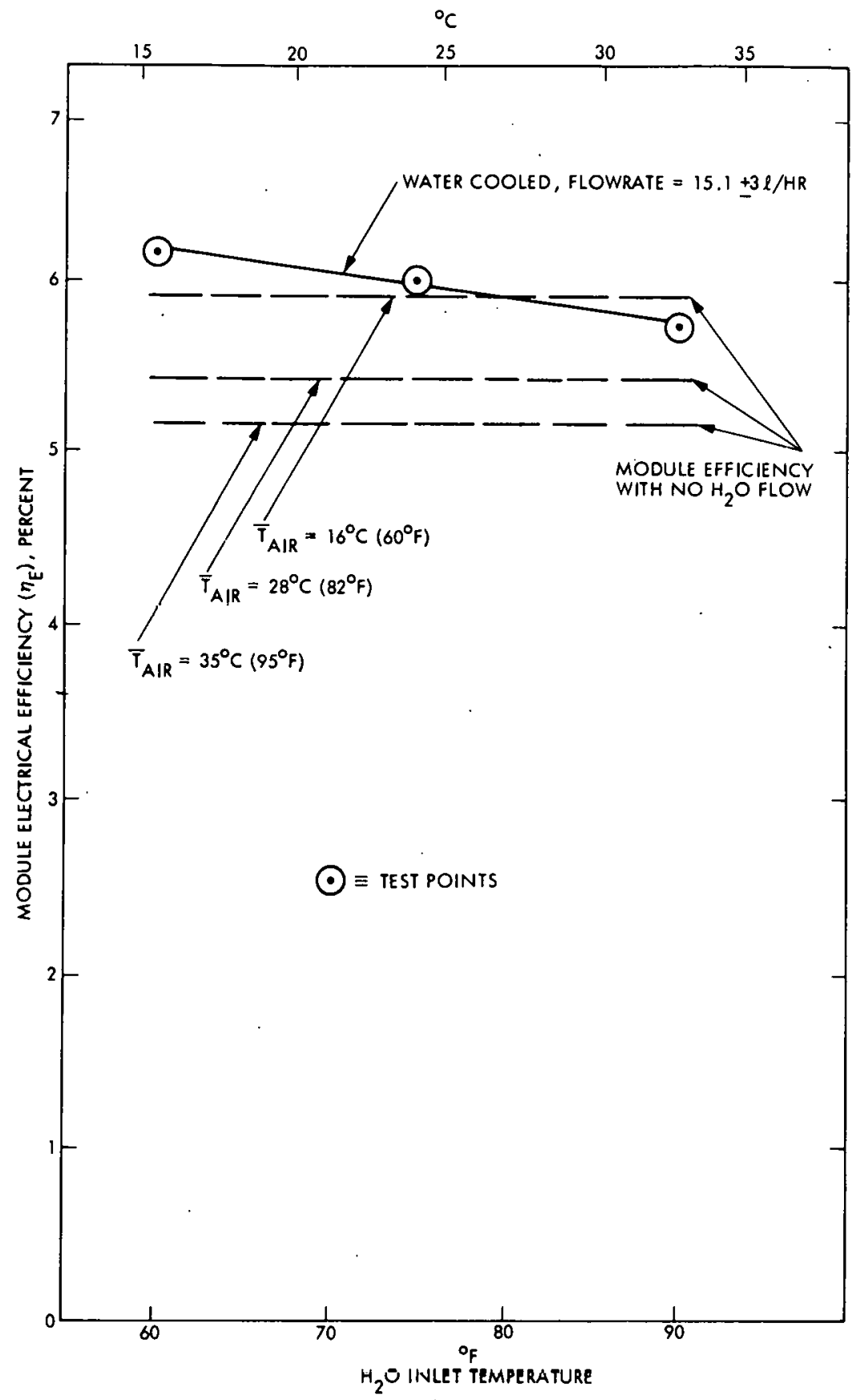

Figure 5-2. Electrical Efficiency of a Water-cooled Flat Plate Photovoltaic Module 


\section{B. COMBINED PHOTOVOLTAIC AND SOLAR WATER HEATING MODULE}

Absorber area requirements for heating water or some other fluid for home space and hot water heating are very large. For example, Reference 3 shows that locally the solar absorber area required for an average home is 37.2 square meters ( 400 square feet). This same home in the high desert of California requires 69.7 square meters (750 square feet) of absorber area. Solar House I at Fort Collins, Colorado (Reference 4) uses all of the roof area facing south (71.3 square meters) as solar collector area. Therefore, there will be many localities in which sufficient south-facing residential roof space is not available for both photovoltaic and solar heating modules.

Since solar cells have a solar absorbance as good as the average black absorber, the cells can replace the black coating of the solar water heater without significantly affecting its heating characteristics. However, electrical performance is significantly degraded by the one or two glass layers covering the absorber plate to minimize the front thermal losses. Tests were performed to evaluate the reduction in electrical efficiency that results from the marriage of a photovoltaic and solar heating module.

Figure 5-3 illustrates the combined module. The Spectrolab Block I module used previously for water cooling tests was surrounded on the backside by $7.6 \mathrm{~cm}$ of Foamglas insulation. The Foamglas is an excellent insulator and has structural characteristics allowing it to be machined to the desired configuration. Double strength window glass $0.32 \mathrm{~cm}$ thick was used for the glazing. Separation distance between the glass and the photovoltaic module (single glass configuration) was $1.27 \mathrm{~cm}$.

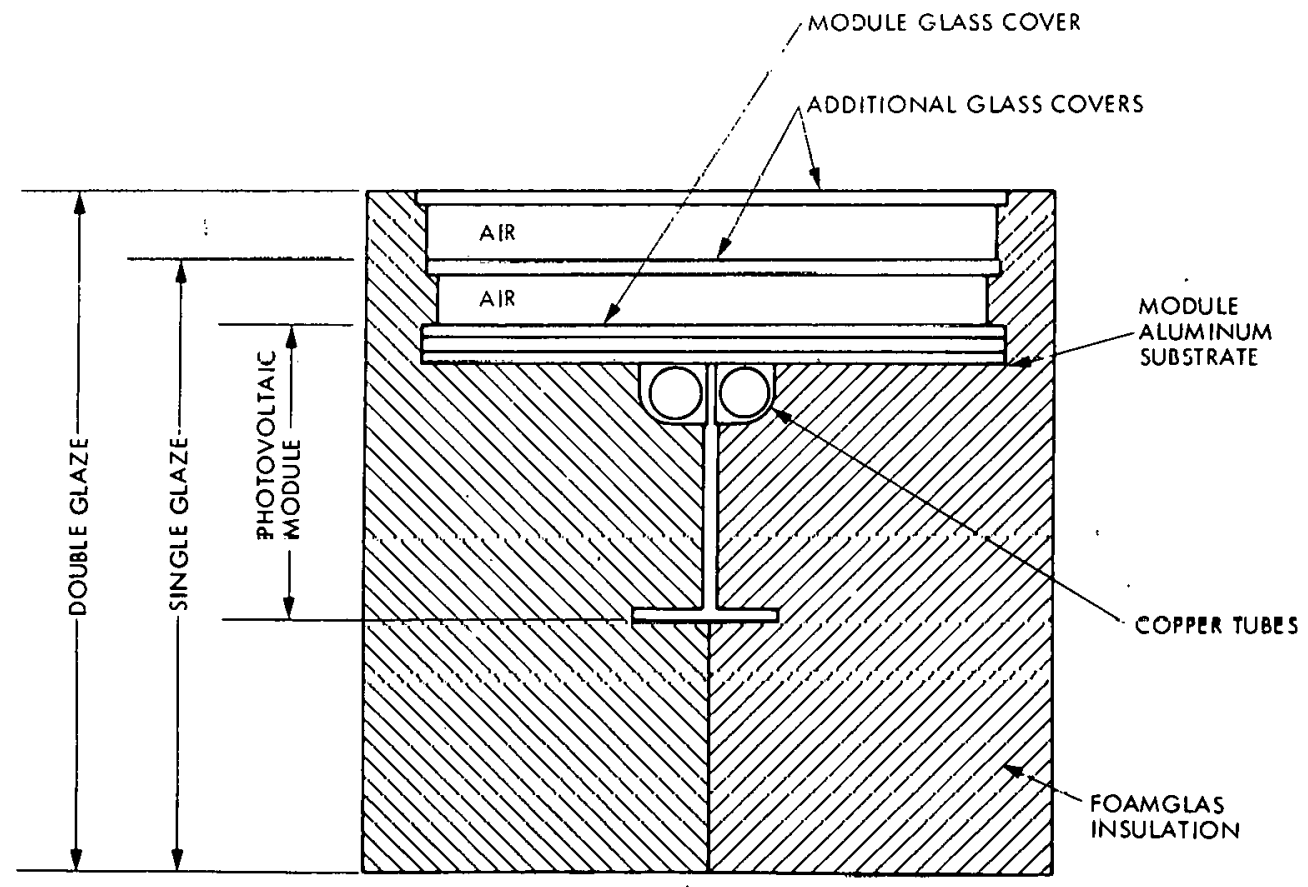

Figure 5-3. Combined Module Configuration 
The module was mounted in an east-west direction to minimize shadowing of the cells. The active side of the module was normal to the sun at solar noon. Water flow was from east lu west at $15.1 \pm 3$ liters per hour. This flow rate corresponds to 4.5 gallons per hour per square foot of absorber area and is about three times that commonly used in solar water collectors. The test flow rate was the lower practical limit for the circulation equipment and minimized the electrical mismatch losses due to different cell temperatures. Cell temperature differences of up to $7^{\circ} \mathrm{C}$ (cell near the water inlet compared to a cell at the water outlet) can be expected at the lower flow rate. The higher test flow rate cut this difference in half. In an actual system, the pump requirements will dictate the more common lower flow rate and an additional 1\% to $2 \%$ decrease in photovoltaic power is probable.

Three tests were carried out. In the first test a single glass was used, and the water increased linearly up to $54^{\circ} \mathrm{C}\left(130^{\circ} \mathrm{F}\right)$ by 1400 PST. The serond test was carried out using a double glass configuration, and the results showed approximatley the same water temperature profile. In the third test, also with the double glass, an electrical heater was turned on at 10:45 PST to simulate a slightly higher temperature system. The final water temperature reached was $64.4^{\circ} \mathrm{C}$ $\left(148^{\circ} \mathrm{F}\right)$. Figure 5-4 presents cell temperature as a function of time for these three tests plus the cell temperature for the same photovoltaic module in a normal field installation with air cooling only. Cell temperatures for the first half of the morning for the combined configuration are similar to, and on occasion may be lower than the air-cooled-only configuration depending on the initial temperature of the storage water. By mid or late morning, however, the cell temperature for the combined configuration exceeds that of the air-cooled-only configuration, and it remains significantly warmer throughout the afternoon, during which period the temperature of the air cooled module actually decreases. Since power for the photovoltaic only module decreases at a rate of $0.4 \%$ per ${ }^{\circ} \mathrm{C}$ increase in cell temperature, the higher module temperatures, especially in the afternoon, contribute significantly to lessening the electrical performance. Figure 5-5 presents the electrical efficiency $\left(n_{\varepsilon}\right)$ as a function of time for the same tests and cell temperatures corresponding to those presented in Figure 5-4.

Tuble 5-1 is a cummary of electrical efficiency ( $\eta_{\varepsilon}$ ) for an 8-hour operating period, including the solar noon measurements. To obtain the 8-hour average it was necessary to extrapolate the curves in Figure 5-5. The $n_{\varepsilon}$ of the photnvoltaic. module alone was assumed to be the same in the morning as measured in the afternoon. Analysis indicates that this is approximately true, but generally the efficiency will be slightly higher in the morning because of cooler air temperatures. The effect of $\therefore$ i.iule glass, of touble glaos, and of the higher afternoon water temperatures on $\eta \varepsilon$ are illustrated in Table 5-1. It is also apparent that $\eta_{\varepsilon}$ for the noon hour is lcss than the daily average for the photovoltaic module alone but greater than the 8-hour daily average for the combined configurations. Compared to the daily average, the noon average performance predicts a higher performance by $2 \%, 7 \%$, and $9 \%$, for the single and two double glass configurations, respectively, and a $2 \%$ lower performance for the photovoltaic only module. 


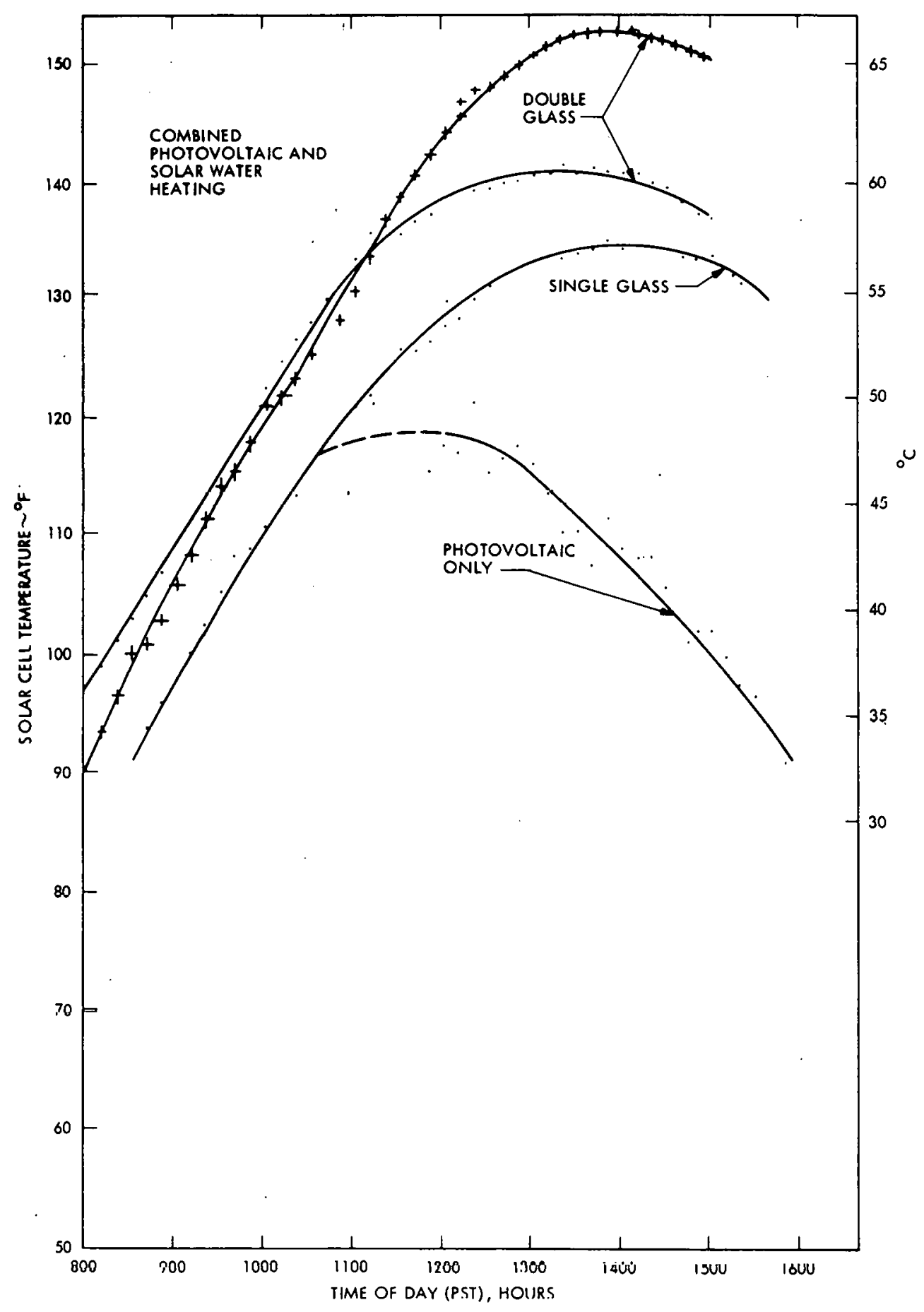

Figure 5-4. Solar lell l'emperature vs Time of Day for Photovoltaic Only and Combined Photovoltaic/Thermal Collectors 


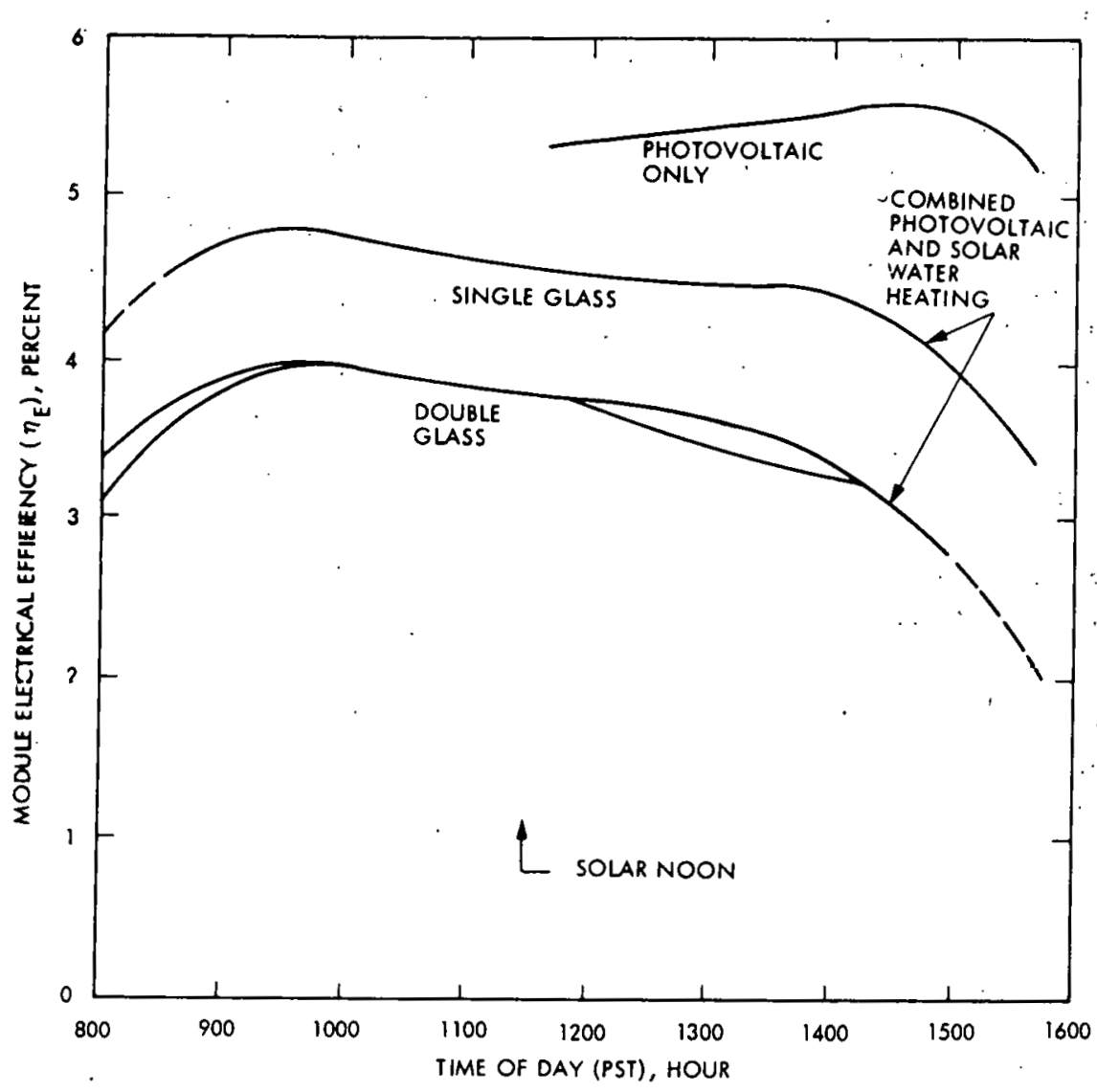

Figure 5-5. Electrical Efficiency vs Time of Day for Photovoltaic Only and Combined Photovoltaic/Thermal Collectors

Table 5-1. Electrical Efficiency $\left(n_{\varepsilon}\right)$ of Photovoltaic Only and Combined Photovoltaic/Thermal Collectors (5)

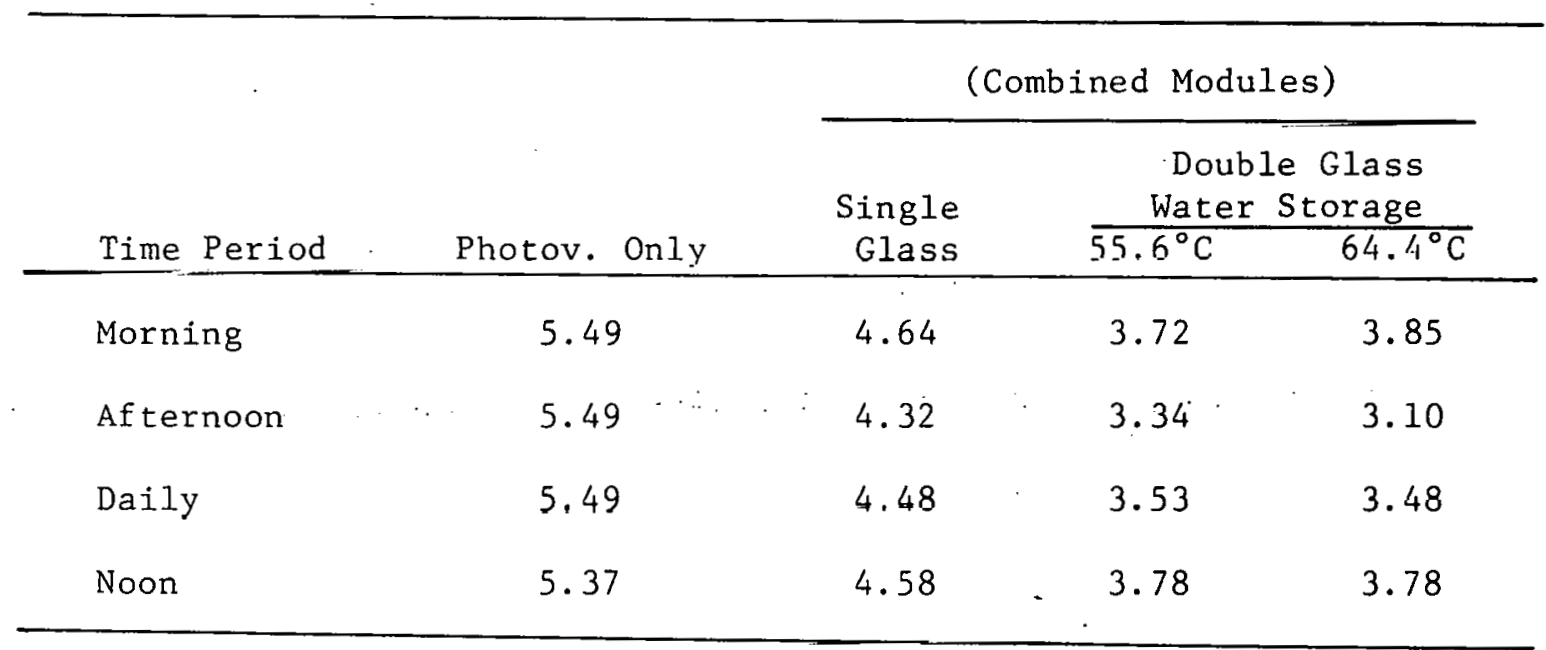


The purpose of the last two tests was to estimate the change in $n_{\varepsilon}$ which occurred with a change in water storage temperature. The comparison was less than ideal because of the difference in the initial water storage temperatures. However, assuming morning values for $\eta_{\varepsilon}$ to be the same, and basing the estimated change in $n_{\varepsilon}$ only on the change in afternoon performance, the estimated values for electrical efficiency are minimum but representative of actual values. The minimum change in daily electrical performance for a change in water storage temperature $\left(\Delta n_{\varepsilon} / \Delta T_{\text {STR.) }}\right.$ is thus estimated at $0.014 \%$ per ${ }^{\circ} \mathrm{C}$ for the double glass configuration. Figure 5-6 graphically illustrates this effect. Approximately a $50 \%$ reduction in $n_{\varepsilon}$ from that for the photovoltaic module alone would be approached with a combined module and $100^{\circ} \mathrm{C}$ fluid storage, as occurs for Solar House 1 .

Since the danger of a decrease in flow rate is of concern with this type of combined module, a test was made to illustrate this effect. Additional heat was added to the storage water and the cell temperature was elevated to $75.6^{\circ} \mathrm{C}$ by $11: 00$ PST, at which time the flow was stopped. The cell temperature continued to increase to a maximum of $91.1^{\circ} \mathrm{C}$ at $12: 30$ PST. This temperature is not cause for concern, however such a failure on a hot day and with a thermally more efficient system would

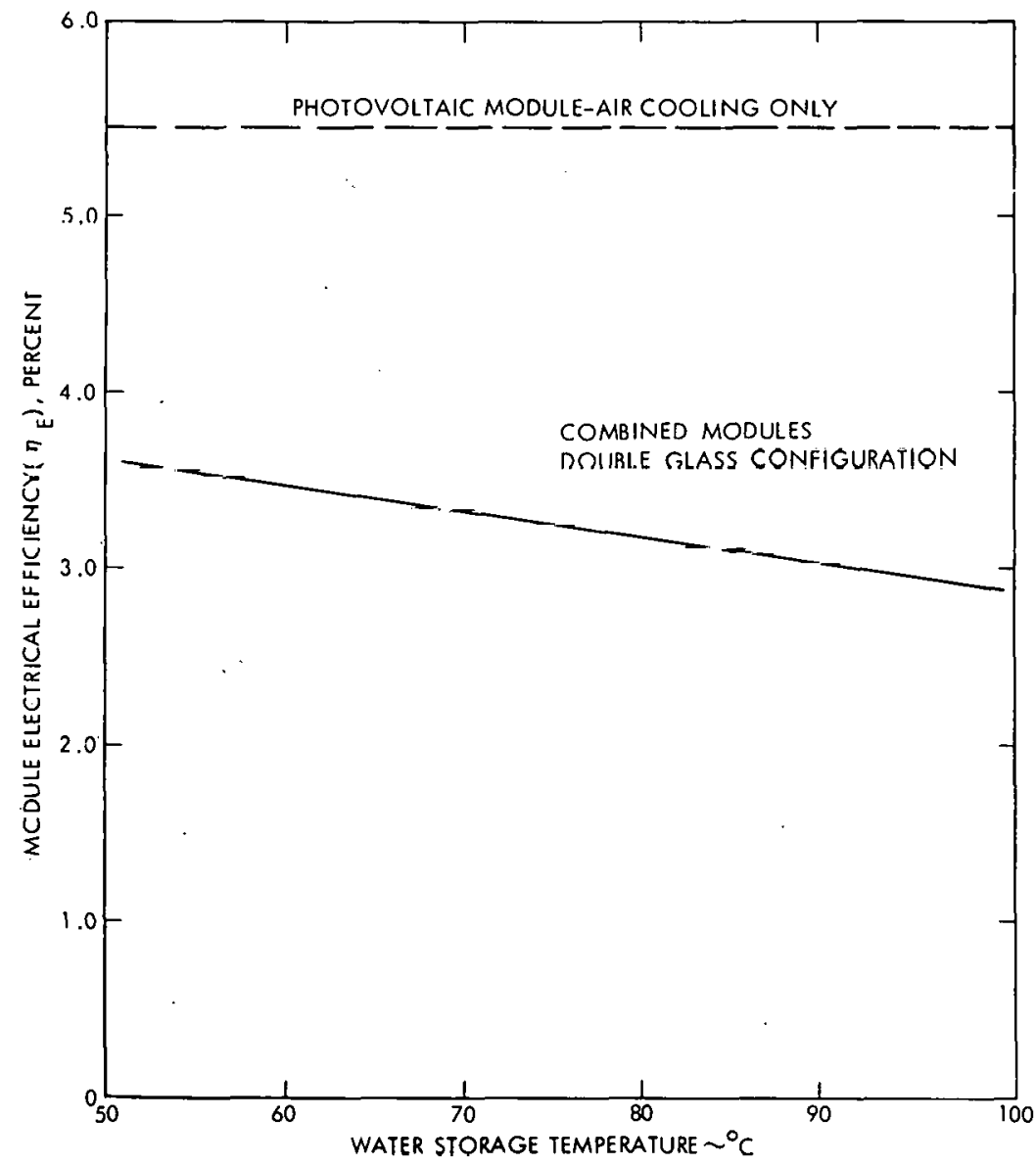

Figure 5-6. Effect of Water Storage Temperature on the Electrical Efficiency of a Combined Photovoltaic/Thermal Collector 
result in cell temperatures greater than $100^{\circ} \mathrm{C}$ and perhaps as high as $130^{\circ} \mathrm{C}$. New material problems may begin to show up at the latter temperature.

Table 5-2 is a cost summary in $\$$ per wat formulated from the preceding efficiencies and 1980 and 1986 photovoltaic module cost goals. The optimistic estimates assume that all non-cell-related costs are absorbed by the solar water heating module. Sometime in the 1980 to 1984 time period the marriage configurations will be cost effective in remote applications. Beginning in 1986, the combined module for moderate storage temperatures could reduce the cost to less than 50 c per watt. For residential applications the combined module will be most desirable.

Table 5-2. Preliminary Economic Implications of Combined Collectors

\begin{tabular}{|c|c|c|c|c|c|c|c|}
\hline \multirow{2}{*}{$\begin{array}{c}\text { Collector } \\
\text { Configuration }\end{array}$} & \multirow{2}{*}{$\begin{array}{c}\text { Water } \\
\text { Exit Temp } \\
\left({ }^{\circ} \mathrm{C}\right)\end{array}$} & \multicolumn{3}{|c|}{$\begin{array}{l}1982 \text { Cusi } \\
\text { (\$/watt) }\end{array}$} & \multicolumn{3}{|c|}{$\begin{array}{l}1986 \text { Cost } \\
(\$ / \text { wat } t)\end{array}$} \\
\hline & & Cells & Sub & Total & Cells & Sub & Total \\
\hline PV Only & - & 1.80 & 0.20 & 2.00 & 0.34 & 0.16 & 0.50 \\
\hline $\begin{array}{l}\text { Combined } \\
\text { (single glass) }\end{array}$ & 60 & 2.21 & 0 & 2.21 & 0.40 & 0 & 0.40 \\
\hline \multirow{2}{*}{$\begin{array}{l}\text { Combined } \\
\text { (double glass) }\end{array}$} & 60 & 2.45 & 0 & 2.45 & 0.46 & 0 & 0.46 \\
\hline & 100 & 2.70 & 0 & 2.70 & 0.51 & 0 & 0.51 \\
\hline
\end{tabular}

\section{MODULE WITH A PHASE CHANGE MATERIAL}

There have been several applications, both terrestrial and in space, in which the latent heat of fusion is used to absorb excess energy to limit an otherwise unacceptable rise in temperature. A variety. of phase change materials are available so that correspondence between the desired melting point and application are easily obtainable if cost is not a primary consideration. Cost is a primary factor for the LSA Project, and only a few of the waxes have the potential to be a cost effective means of lowering or limiting the photovoltaic module temperature.

Table 5-3 (from Reference 5) presents the properties of three waxes whose projectcd cost pcr lb for large commercial quantities show potential for thermal storage applications. Of these waxes, Eicosane has a melting point $\left(36,7^{\circ} \mathrm{C}\right) 4^{\circ} \mathrm{C}$ to $7^{\circ} \mathrm{C}$ less than the NoCT of the block II modules $\left(41^{\circ} \mathrm{C}\right.$ to $\left.47^{\circ} \mathrm{C}\right)$. Therefore, if the phase change material were successful in absorbing the excess thermal energy, an improvement in power of $2 \%$ to $3-1 / 2 \%$ could be expected. 
Table 5-3. Material Properties of Candidate Fusion Materials

\begin{tabular}{|c|c|c|c|}
\hline Property & Paraffin Wax & Eicosane & $\begin{array}{c}\text { Carbowax } \\
1000\end{array}$ \\
\hline Formula & $\begin{array}{l}\text { Various } \mathrm{C}_{\mathrm{x}} \\
\mathrm{H}_{2 \mathrm{x}+2}\end{array}$ & $\mathrm{C}_{20} \mathrm{H}_{42}$ & \\
\hline Molecular weight & Approx. 300 & 282 & $950-1050$ \\
\hline $\begin{array}{l}\text { Density } \\
\quad \text { Solid } 1 \mathrm{~b} / \mathrm{ft}^{3} \\
\text { Liquid } \mathrm{lb} / \mathrm{ft}^{3}\end{array}$ & 51 & $\begin{array}{l}53.4 \\
48.6\end{array}$ & 71.8 \\
\hline Melting Temperature $\left({ }^{\circ} \mathrm{F}\right)$ & 116 & 96.1 & $100-105$ \\
\hline Latent heat (BTU/1b) & 65 & 106 & 67 \\
\hline $\begin{array}{l}\text { Specific heat } \\
\text { Solid }\left(\mathrm{BTU} / 1 \mathrm{~b}^{\circ} \mathrm{F}\right) \\
\text { Liquid }\end{array}$ & $\begin{array}{l}0.72 \\
0.50\end{array}$ & $\begin{array}{l}0.53 \\
0.48\end{array}$ & 0.54 \\
\hline $\begin{array}{l}\text { Coefficient of Thermal } \\
\text { Expansion }\left(1 /{ }^{\circ} \mathrm{F}\right)\end{array}$ & & 0.00016 & 0.00042 \\
\hline Expansion in phase change $(\%$ & & 15 & \\
\hline $\begin{array}{l}\text { Thermal conductivity } \mathrm{BTU} / \mathrm{hr} \\
\mathrm{ft} \mathrm{C}^{\circ} \mathrm{F} / \mathrm{ft}\end{array}$ & & 0.0865 & \\
\hline Material Compatibility & No problem & No problem & No problem \\
\hline Hazards & Flanumable & Flaminable & \\
\hline rnat $r / 1 \mathrm{~h}$ & 11 & 25 & 38 \\
\hline Common usage & $\begin{array}{l}\text { Paper } \\
\text { coating }\end{array}$ & $\begin{array}{l}\text { Thermostat } \\
\text { actuation }\end{array}$ & $\begin{array}{l}\text { Rubber and } \\
\text { text1le } \\
\text { industries }\end{array}$ \\
\hline Annual production & 347,000 Tons & $30-40$ Tons & \\
\hline
\end{tabular}

A Spectrolat Block I ...udulc was cncloced on the backside as illustrated in Figurs 5-7. The module aluminum suhstrate was in direct contact with the wax. The test configuration was that normally used for the NOCT measurement with the module mounted in an array and surrounded either by other modules or by black plates simulating other modules. The tilt angle of the array was adjusted to maintain the module normal to the sun at solar noon. Tcchnical grade Eicosane and common canning paraffin were used for the phase change materials. Technical grade. 


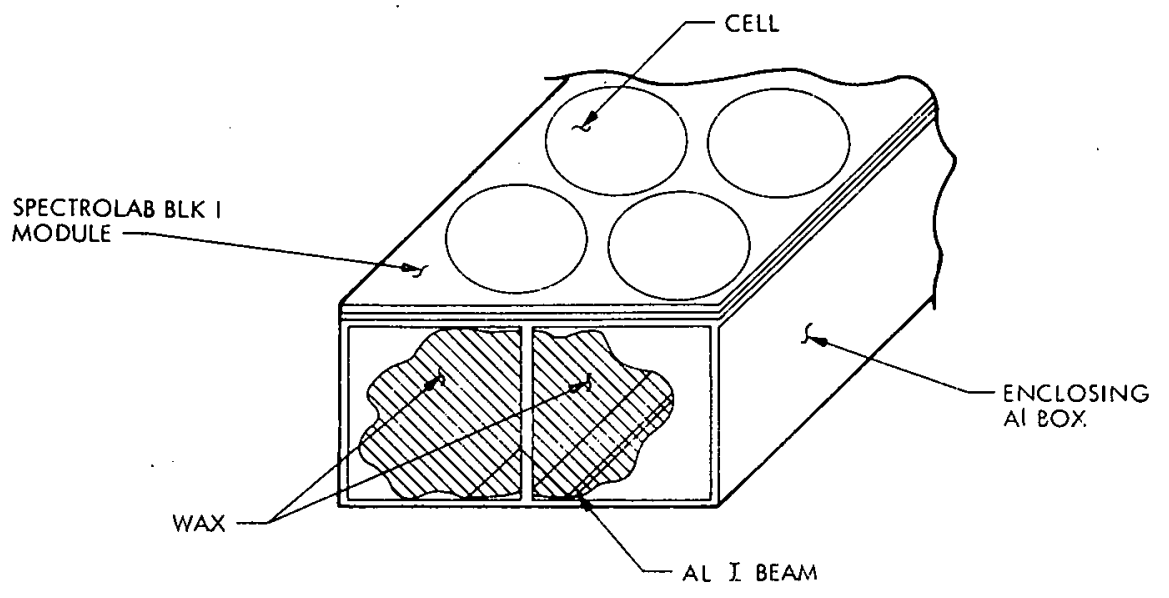

Figure 5-7. Phase Change Photovoltaic Module

Eicusane mells at aboul $2^{\circ} \mathrm{C}$ lower than the Eicosane shown in Table 5-3. Because of the impurities in this grade of Eicosane the latent heat will also be slightly less then that shown in the table. The canning paraffin was observed to melt at about $6^{\circ} \mathrm{C}$ higher than that indicated in the table. It was purchased at a local supermarket for $43 c$ per pound (compared to 1lc per pound in Table 5-3) and the technical grade Eicosane costs $\$ 1.70$ per pound. The pure Eicosane was available for $\$ 11.72$ per pound from the same vendor (Humphrey Chemical Corporation).

The electrical efficiency $\left(n_{\varepsilon}\right)$ is based on the photovoltaic module area and is as defined previously. Table 5-4 summarizes $\eta_{\varepsilon}$ for the three tests. Performance is based on 8-hour operation. The Spectrolab module has a very low NOCT $\left(41^{\circ} \mathrm{C}\right)$, that was made lower by the attachment of the aluminum box. Therefore, the small improvement of $1.2 \%$ (paraffin) and $1.4 \%$ (Eicosane) was about as expected. The improvements are minimum since the air temperature as well as the solar intensity was the same or greater on the days during which the wax was used. As a result higher cell temperatures would have resulted without use of wax on those days.

'labLe b-4. ELLectrical Ëṫiciency ( $\eta_{\varepsilon}$ ) Kesults

\begin{tabular}{ccc}
\hline $\begin{array}{c}\text { Phase Change } \\
\text { Material }\end{array}$ & $\eta_{\varepsilon}(\%)$ & Improvement (\%) \\
\hline None & 5.73 & 0.0 \\
Canning paraffin & 5.80 & 1.22 \\
Tech grade Eicosane & 5.81 & 1.40 \\
\hline
\end{tabular}


Figure 5-8 shows the cell temperature for each test, and the effect of the wax is more evident. During the test only a portion of the Eicosane melted and no melting occurred with the paraffin because of its high melting point. The heated wax keeps the cell temperature higher during the last two hours of the day. Because of radiation to the night sky, the module and wax cool to less than the night air temperature, which increases the thermal storage capacity and accounts for the initial lower cell temperatures.

These tests have illustrated that better photovoltaic performance can be obtained with a phase change material. However, current prices of the waxes make the technique too expensive. Even with predicted future price reductions (assuming increased production), using a phase change material would probably only be cost effective in some of the remotest applications.

\section{ELECTRICAL PERFORMANCE OF DIRTY MODULES}

The module short-circuit current was measured in natural sunlight at solar noon for several angles of incidence obtained by changing the tilt angles of the module. Figure 5-9 summarizes the measurements for clean modules having a front surface of glass and Sylgard 184 . When the module is clean, the short-circuit current varies as the cosine of

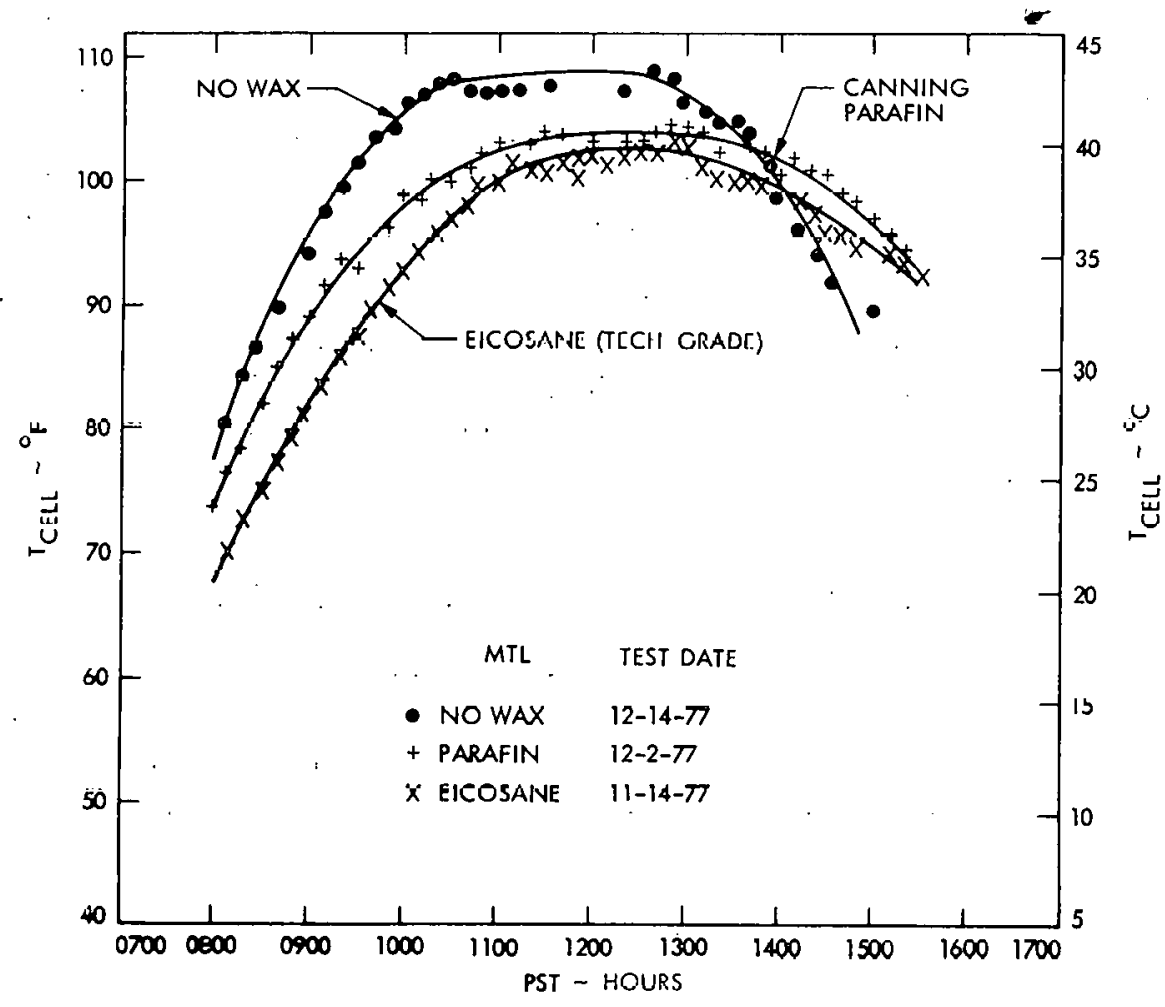

Figure 5-8. Cell Temperature During Tests with Phase Change Materials 


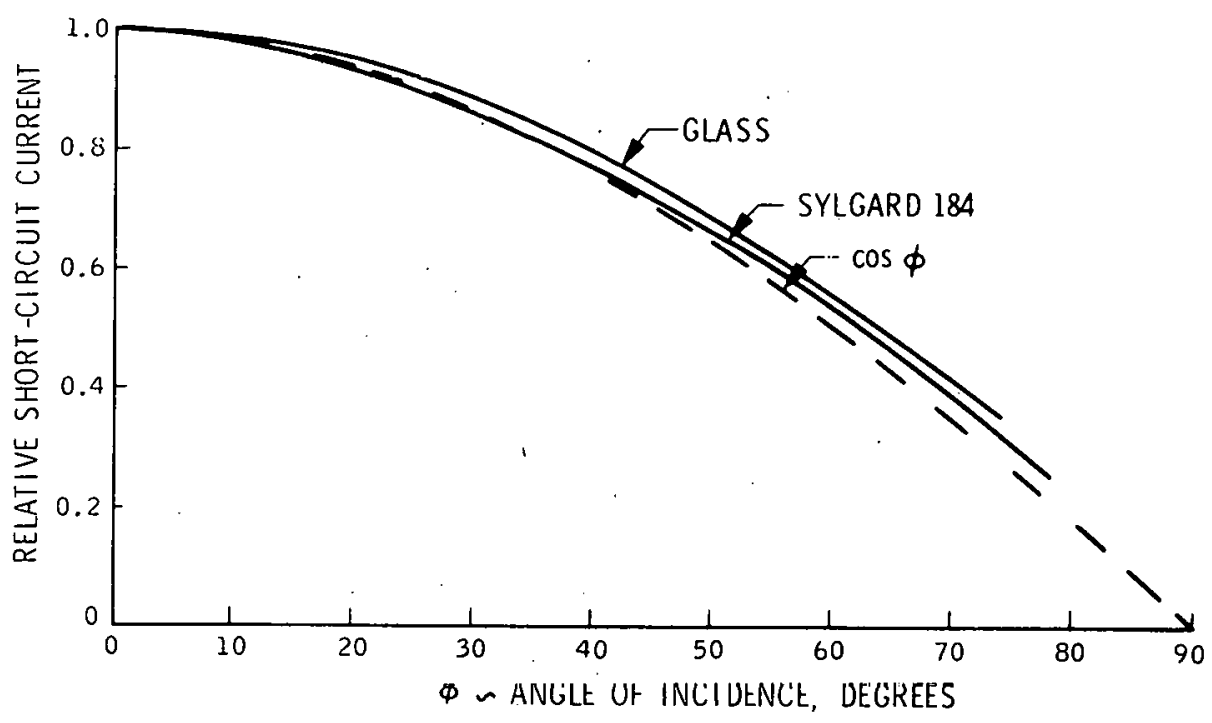

Figure 5-9. Short-Circuit Current vs Angle of Incidence

the incidence angle for both types of modules. Figure 5-10 is a similar plot for the Sylgard 184 module illustrating the effect of dirt accumulation. After one week of dirt accumulation the degradation is about $2 \%$ and constant for angles of incidence up to $60^{\circ}$. After one month the degradation is $6.5 \%$ at normal incidence and increases almost linearly to $11.5 \%$ at an angle of incidence of $60^{\circ}$

These tests show that normal incidence measurements of the effect of dirt are only representative of "light" dirt accumulation as might be expected for modules washed at two-week intervals. In a "severe" dirt environment, the degradation is greater than that indicated by the normal measurements. 


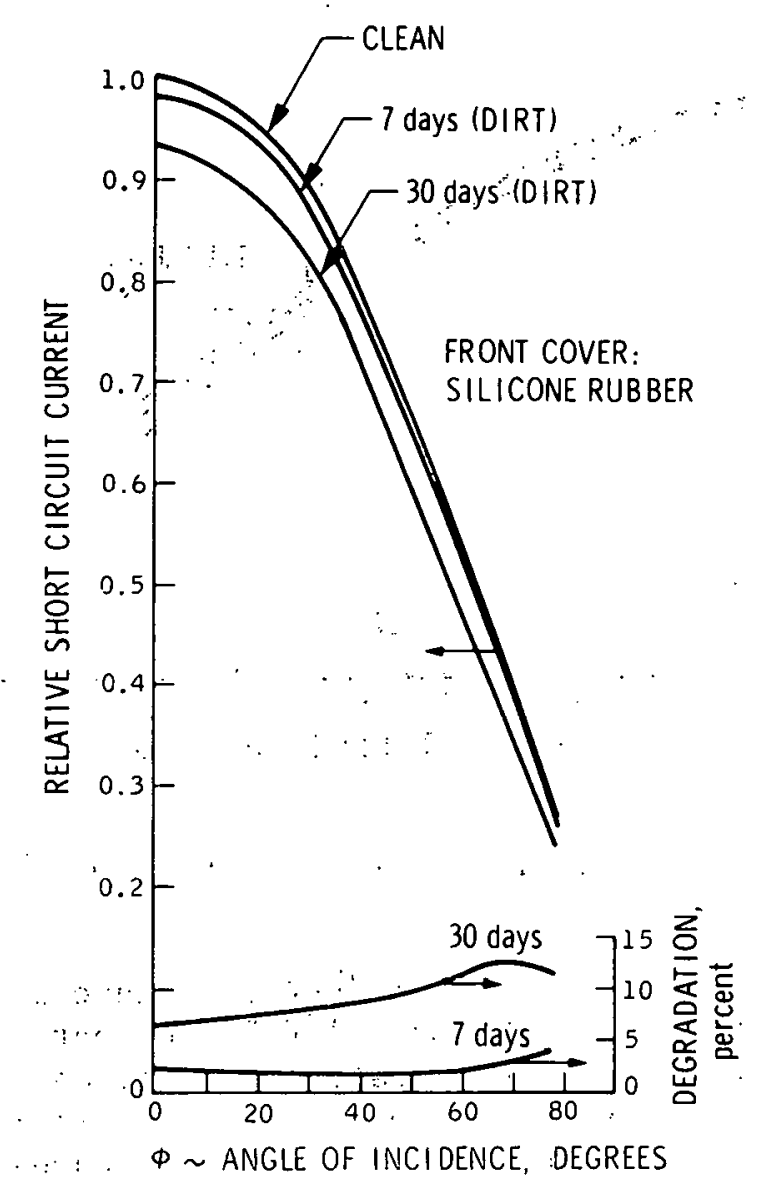

Figure 5-10. Short-Circuit Current vs Angle of Incidence and Dirt Buildup 


\section{A. PHOTOVOLTAIC MOdULE THERMAL PERFORMANCE}

Figure.6-1 summarizes the NOCT measurements of the vendor-supplied modules and illustrates the trend in NOCT. Care in thermal design and cost considerations are forcing the NOCT into the $43^{\circ} \mathrm{C}$ to $48^{\circ} \mathrm{C}$ range.

A good thermal design utilizes a thin substrate with high infrared emission and low solar absorption, and the module has no air voids. Very little additional thermal improvement is possible with the flat plate configuration. This is apparent on examining the NOCT efficiency $\left(\eta_{\text {NOCT }}\right)$ and the two parameters whose product results in NOCT. As shown in Table 6-1, $\eta_{\text {NOCT }}$ is between 0.90 and 0.93 for the Block II modules. If the lnopst maxjmum power soefficiont (Tablo 6-1) io combincd with the minimum temperature difference $\left(\right.$ NOCT $-28^{\circ} \mathrm{C}$ ), then $\eta_{\text {NOCT }}$ is equal to 0.94 . Because of cost, 0.94 probably represents a practical upper limit of $\eta_{\text {NOCT }}$ obtainable for the flat plate configuration. Good thermal design, as typified by the Block II modules, results in thermal performance within $1 \%$ and $4 \%$ of that probably obtainable from the thermally optimum realistic design.

B. OTHER TESTS

1. Water Conled Morli1e.

Significant improvement in module performance is possible by cooling the module with water. However, cooling with water is not expected

Table 6-1. NOCT and $n_{\text {NOCT }}$ Summary

\begin{tabular}{|c|c|c|c|c|c|}
\hline $\begin{array}{l}\text { Block II } \\
\text { Module }\end{array}$ & $\begin{array}{l}\text { NOCT } \\
{ }^{\circ} \mathrm{C}\end{array}$ & $\begin{array}{c}\text { Max Pwr } \\
\text { Coeff. }\end{array}$ & $\begin{array}{l}\text { NOCT } \\
-28^{\circ} \mathrm{C}\end{array}$ & $=\eta_{\text {NOCT }}$ & $\begin{array}{c}\text { No. of Tests } \\
\text { Performed }\end{array}$ \\
\hline Sensor Tcch & 43.0 & .00505 & 15.0 & .924 & 6 \\
\hline Spectrolab & 41.1 & .00524 & 13.1 & .931 & 9 \\
\hline Solarex & 47.0 & .00451 & 19.0 & .914 & 6 \\
\hline Soliar Puwte & 46.0 & .00546 & 18.0 & .902 & 2 \\
\hline
\end{tabular}


to be cost effective unless the application already involves pumping of the water (irrigation, swimming pools, etc.), or unless a gravity water feed system is possible.

2. Combined Photovoltaic and Solar Water Heating Module

Tests and cost estimates indicate that a combined photovoltaic and solar water heating module might be cost effective in the mid 1980's. Sandia is currently evaluating several combined thermal/photovoltaic collectors. Both water and air heating modules are included in this study.

\section{Combined Photovoltaic and Thermal Storage System}

Reducing the module temperature by using a phase change material is not coat cffcctive. If thermal cncrgy jtorcd in the phasc change material is alșo utilized, a combined photovoltaic and thermal storage system may prove to be cost effective. An example of this combination is illustrated in Figure 6-2. The concept employs the lightweight solar dome developed by Boeing, with paraffin wax as the phase change material for thermal storage. Since the wax is totally contained, the building return air can, on command, be diverted to and heated directly in the combined photovoltaic and thermal storage area. Water at city line pressure is also routed through the wax for preheating prior to entering the normal water heater.

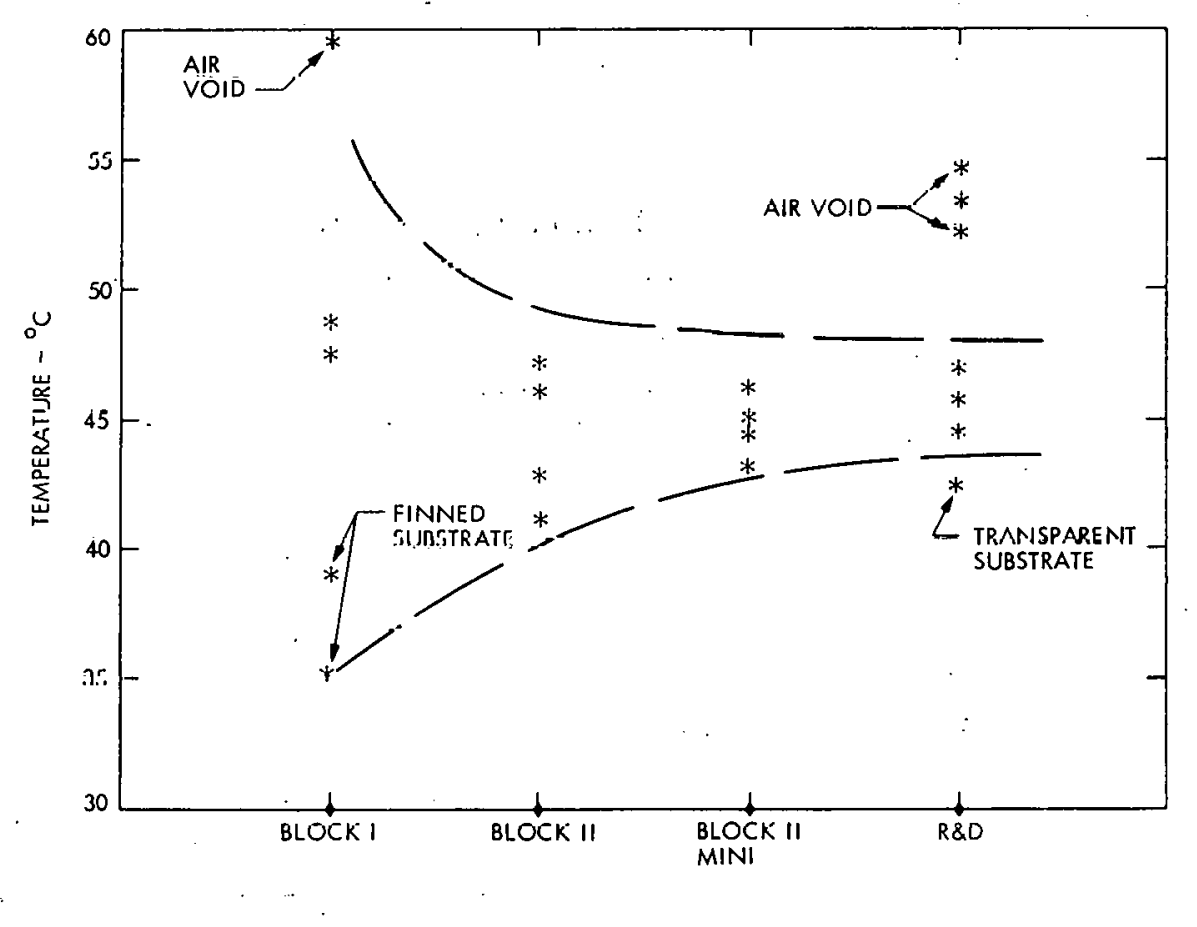

Figure 6-1. NOCT Summary 
At the wax melting point, more energy can be stored with about $15 \%$ less weight than with water. Therefore, this type of system will be better suited for roof (apartment and industrial buildings) and residential attic installations. For residential installation the dome would be replaced by glass, and double glass may be desirable to minimize nighttime losses. Optimization of this concept will vary with the application. However, eliminating the secondary loop by placing the thermal storage system in the primary water and space heating loops and thus utilizing the existing space heating fan, city water pressure and existing attic or roof space will result in lighter weight and in cost savings which make the concept deserving of additional study.

\section{Electrical Performance of Dirty Modules}

Tests of the effect of dirt indicate that "normal incidence" measurements are actually representative of "light" dirt accumulation. In a "severe" dirt environment, the degradation is greater than that indicated by the normal measurements. As reported in the LSA Quarterly Report of April-June, 1977 , a $6.5 \%$ degradation based nn normal incidence for angles of incidence up to $60^{\circ}$, increases to $8 \%$ when weighted according to the annual energy output as a function of incidence angle.

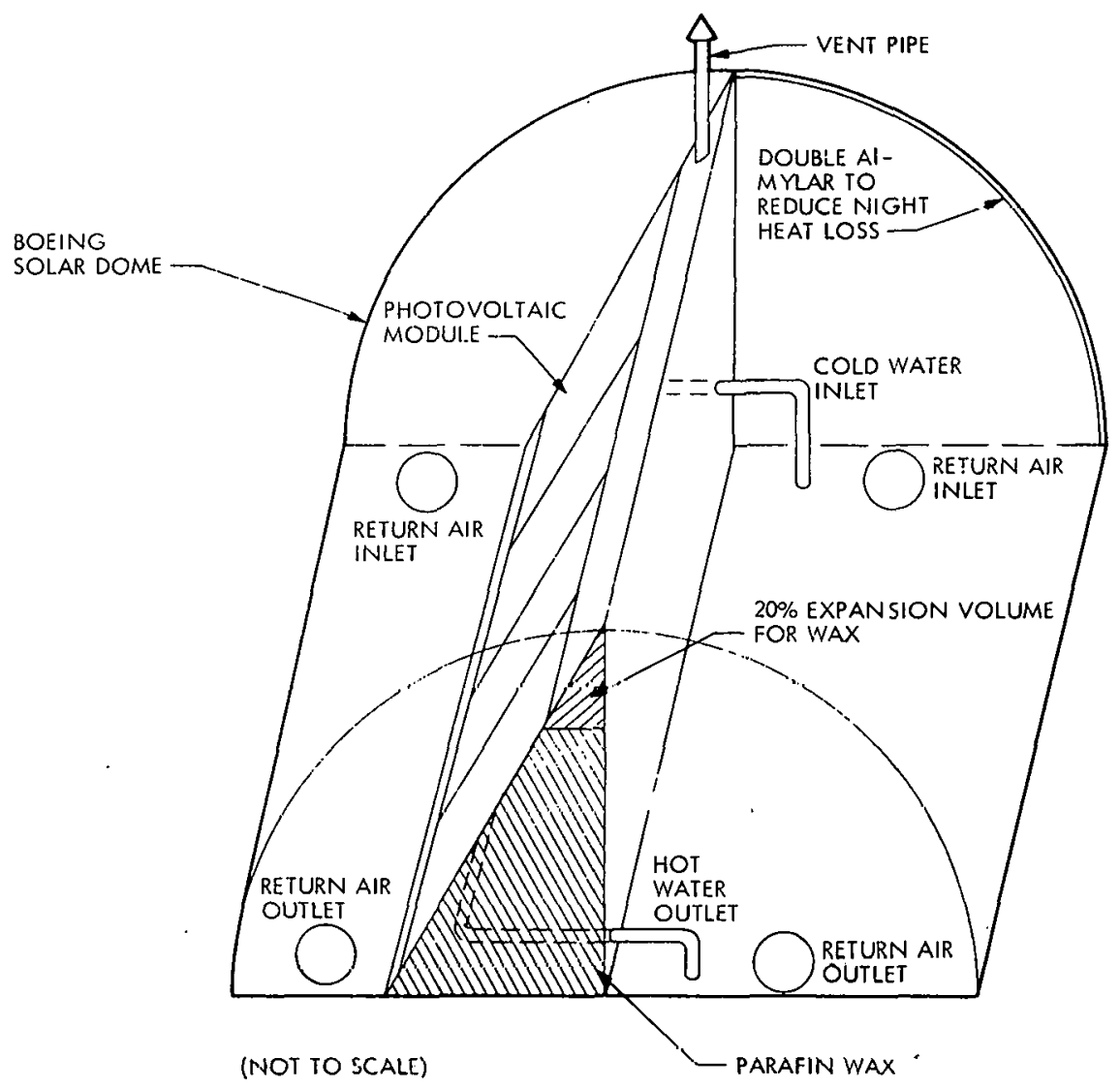

Figure 6-2. Combined Photovoltaic and Thermal Storage System for Space and Hot Water Heating 


\section{REFERENCES}

1. Stultz, J.W. and L.C. Wen, "Thermal Performance Testing and Analysis of Photovoltaic Modules in Natural Sunlight", LSA Task Report 5101-31, Ju1y 29, 1977.

2. Namkoong, D, "Nominal Operating Cell Temperature (NOCT) Test", NASA - Lewis Research Center Document 4220-027, December 5, 1977.

3. Dans, E.S. and L.C. Wen, "Solar Heating and Cooling Systems for Buildings: Technology and Selected Case Studies", JPL Document 5040-9, Rev. 1, November 1975.

4. Loef, G.O.G. and D.S. Ward, "United States Special Format Report: Jesign, lonstruction, and 'lesting of the Colorado State University Solar House 1 Heating and Cooling System", ERDA C00-2577-76/1, June 1976.

5. Shelpuk, B., Joy, R., and M. Cronthamel, "Technical and Economic Feasibility of Thermal Storage", RCA Advanced Technology Laboratories, Camden, New Jersey, Document C00/2591-76/1, June, 1976. 
This appendix provides the approved procedure for determination of solar cell module Nominal Operating Cell Temperature (NOCT) using natural sunlight testing.

\section{A. PURPOSE}

The purpose of this test is to acquire sufficient data to allow an accurate determination of the nominal operating temperatures of the solar cells of a terrestrial solar array module.

By definition, the Nominal Operating Cell Temperature (NOCT) is the module cell temperature under operating conditions in the Nominal Terrestrlal Environment (N'l') which is detined as:

$$
\begin{aligned}
& \text { Insolation }=80 \mathrm{~mW} / \mathrm{cm}^{2} \\
& \text { Air Temperature }=20^{\circ} \mathrm{C} \\
& \text { Wind Average Velocity }=1 \mathrm{~m} / \mathrm{s} \\
& \text { Mounting - Tilted, Open Back, Open Circuit }
\end{aligned}
$$

The NOCT test procedure is based on gathering actual measured cell temperature data via thermocouples attached directly to the cells of interest, for a range of environmental conditions similar to the NTE. The data are then presented in a way that allows accurate and repeatable interpolation of the NOCT temperature.

\section{B. DETERMINATION OF NOCT}

The temperature of the solar cell ( $\mathrm{T}_{\mathrm{cell}}$ ) is primarily a function of the air temperature $\left(\mathrm{T}_{a i r}\right)$, the average wind velocity $(\overline{\mathrm{V}})$, and the total solar insolation (L) impinging on the active side of the solar array module. The approach for determining NOCT is based on the fact that the temperature difference $\left(\mathrm{T}_{\mathrm{cell}}-\mathrm{T}_{\mathrm{air}}\right)$ is largely independent of air temperature and is essentially linearly proportional to the insolation level. Analyses indicate that the linear assumption is quite good for insolation levels greater than about $40 \mathrm{~mW} / \mathrm{cm}^{2}$. The procedure calls for plotting ( $\mathrm{T}_{\mathrm{cel}} \mathrm{l}^{-\mathrm{T}}$ air ) against the insolation level for a period when wind conditions are favorable. The NOCT value is then determined by adding $\mathrm{T}_{a i r}=20^{\circ} \mathrm{C}$ to the value of $\mathrm{T}_{\mathrm{cell}}-\mathrm{T}_{\mathrm{air}}$ ) interpolated for the NTE insolation level of $80 \mathrm{~mW} / \mathrm{cm}^{2}$, i.e., NOCT $=\left(\mathrm{T}_{\text {cell }}-\mathrm{T}_{\mathrm{a}} \mathrm{r}\right)$ | $\mathrm{NTE}+20^{\circ} \mathrm{C}$.

The plot of $\left(\mathrm{T}_{\text {cell }}-\mathrm{T}_{\mathrm{air}}\right)$ vs $\mathrm{L}$ shall be determined by conducting a minimum of two field tests in which the module being characterized is tested under terrestrial environmental conditions approximating the NTE in accordance with the testing guidelines which follow. Each test shall 
consist of acquiring a semicontinuous record of ( $\mathrm{T}$ cell $-\mathrm{T}_{\mathrm{T}} \mathrm{ir}$ ) over a one- or two-day period, together with other measurements as required to characterize the terrestrial environment during the testing period. Acceptable data shall consist of measurements made when the average wind velocity is $1 \mathrm{~m} / \mathrm{s} \pm 0.75 \mathrm{~m} / \mathrm{s}$ and with gusts less than $4 \mathrm{~m} / \mathrm{s}$ for a period of 5 minutes prior to and up to the time of measurement. Local air temperature during the test period shall be $20^{\circ} \mathrm{C} \pm 15^{\circ} \mathrm{C}$. Using only acceptable data as so defined, a plot shall be constructed from a set of measurements made either prior to solar noon or after solar noon which defines the relationship between ( $\mathrm{T}_{\mathrm{cell}}-\mathrm{T}_{\mathrm{air}}$ ) and the solar insolation level (L) for $\mathrm{L} \geq 40 \mathrm{~mW} / \mathrm{cm}^{2}$.*

When $\left(\mathrm{T}_{\text {cell }}-\mathrm{T}_{\text {air }}\right)$ is plotted as a function of $\mathrm{L}$, for average wind velocities less than $1.75 \mathrm{~m} / \mathrm{s}$, results similar to those shown in Figure A-1 are obtained. For the data shown the local air temperature was $15.6^{\circ} \mathrm{C} \pm 4.5^{\circ} \mathrm{C}$ and the wind speed varied from zero to less than $4 \mathrm{~m} / \mathrm{s}$ with an average of $\mathrm{l} \mathrm{m} / \mathrm{s}$. Using the plot of $\left(T_{c e l l}-T_{a i r}\right)$ vs $T_{1}$, the value of ( $\mathrm{T}_{\mathrm{ce}} 11-\mathrm{T}_{\mathrm{air}}$ ) at $\mathrm{NTE}$ is determined by interpolating the average value of $\left(\mathrm{T}_{\text {cell }}-\mathrm{T}_{\text {air }}\right)$ for $\mathrm{L}=80 \mathrm{~mW} / \mathrm{cm}^{2}$. Using the data in Figure $A-1$ as an example, ( $\mathrm{T}_{\mathrm{ce}} 11-\mathrm{T}_{\mathrm{air}}$ ) at NTE is determined to be $22.2^{\circ} \mathrm{C}$. The preliminary value of NOCT is thus $22.2^{\circ} \mathrm{C}+20^{\circ} \mathrm{C}=42.2^{\circ} \mathrm{C}$.

$*$ The two sets of measurements can be combined into a single set provided the average air temperature of the two sets does not differ by more than approximately $5^{\circ} \mathrm{C}$. If the average air temperature is significantly different, the resulting effect appears as an increase in the scatter of the plotted data. As a result the data will be more difficult to fit and a less accurate result is possible.

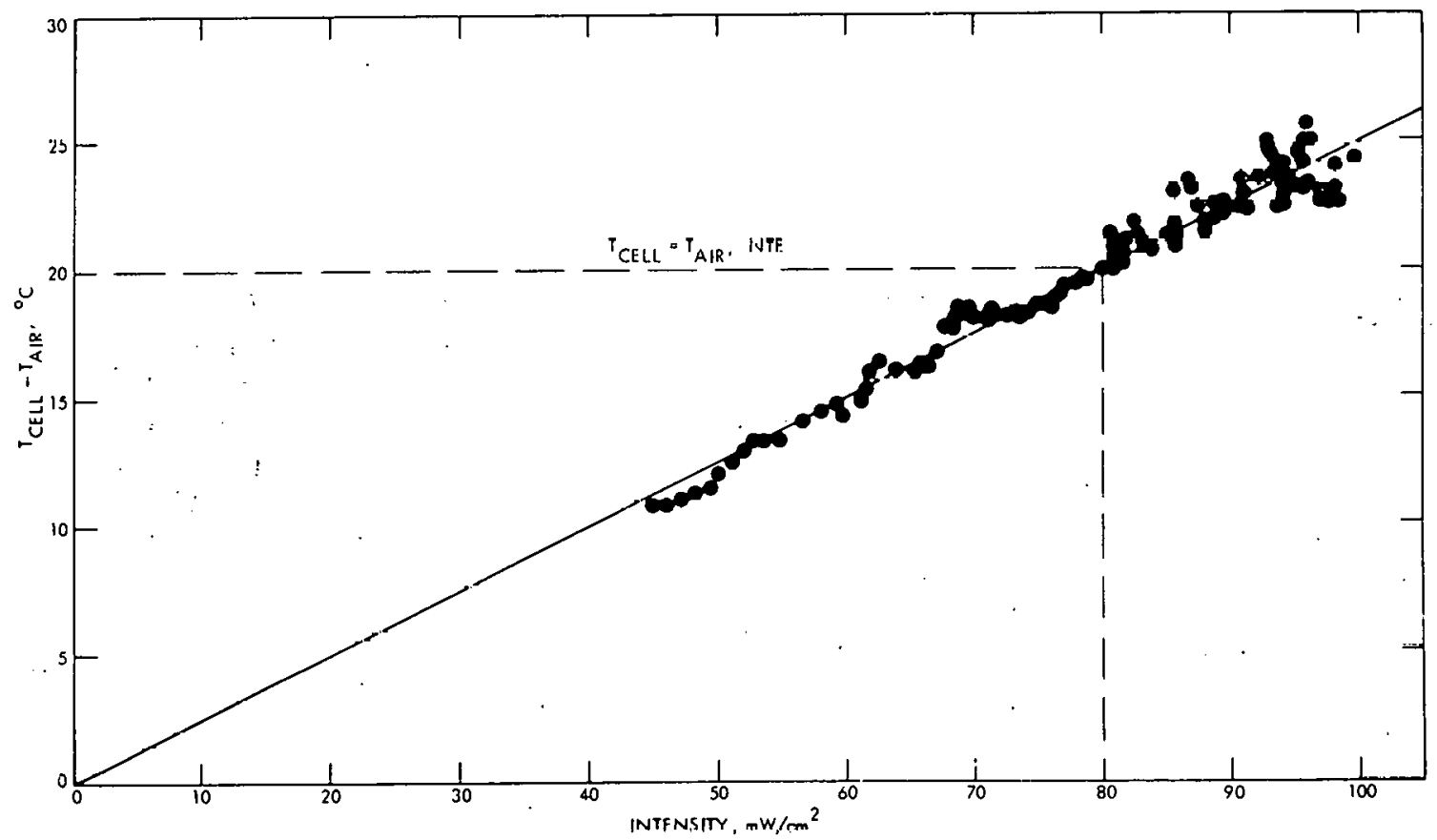

Figure A-1. Tvpical Cel1 Temperature Data 


\section{AIR TEMPERATURE AND WIND CORRECTION}

A correction factor to the preliminary NOCT for average air temperature and wind velocity is determined from Figure A-2. This value is added to the preliminary NOCT and corrects the data to $20^{\circ} \mathrm{C}$ and $1 \mathrm{~m} / \mathrm{s} . \quad \bar{T}_{a i r}$ and $\bar{v}$ are the average temperature and wind velocity for the test period.

For the test data shown in Figure $A-1, \bar{V}$ is $1 \mathrm{~m} / \mathrm{s}$ and $\bar{T}_{a i r}$ is $15.6^{\circ} \mathrm{C}$. From Figure A-2, the correction factor is $0^{\circ} \mathrm{C}$. The NOCT is therefore $42.2^{\circ} \mathrm{C}$.

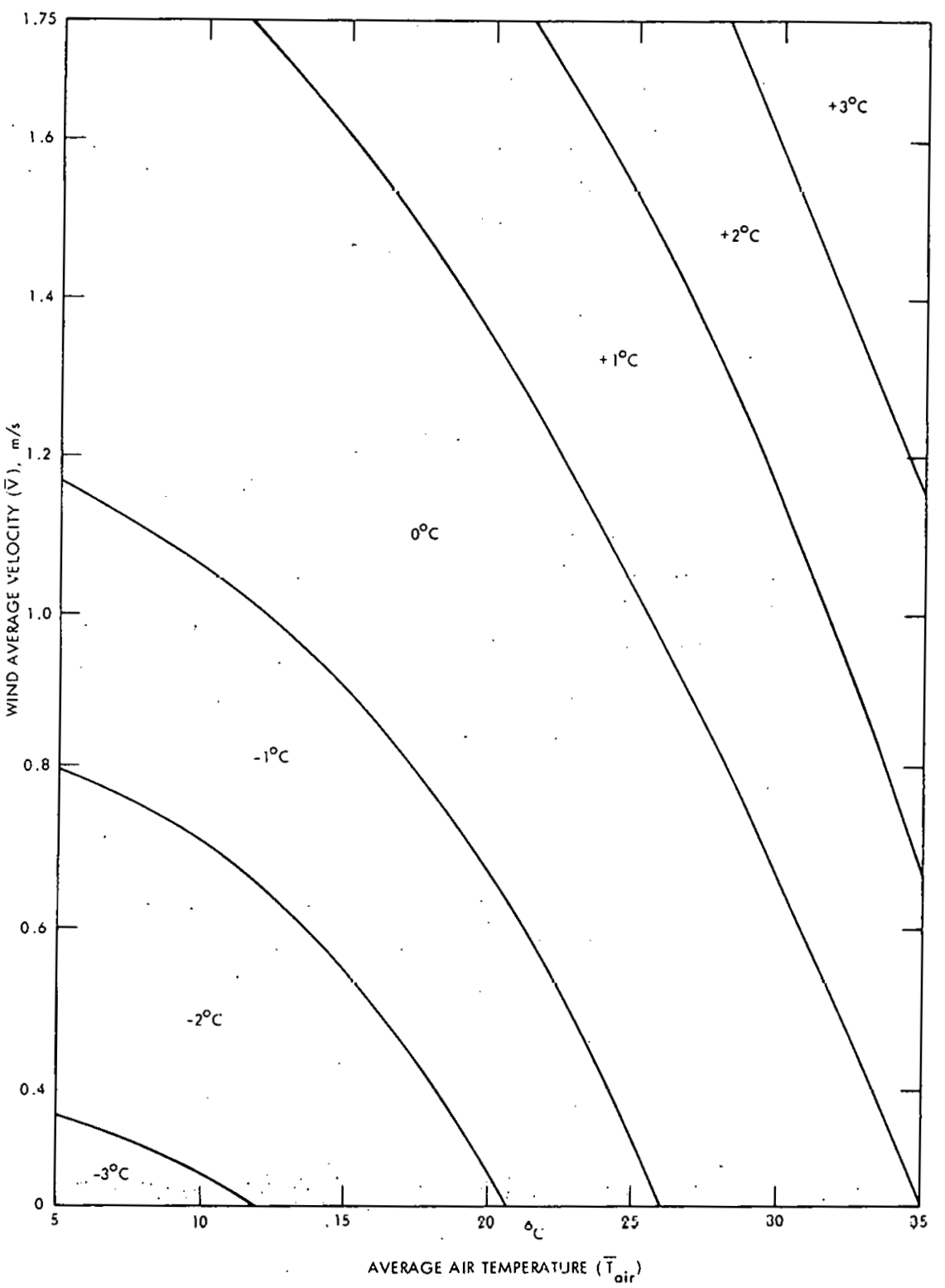

Figure A-2. NOCT Correction Factor 
D. TEST GEOMETRY

1. Tilt Angle.

The plane of the module shall: be positioned so that it is normal to the sun $\left( \pm 5^{\circ}\right)$, at solar. noon.

2. Height

The bottom edge of the module shall be 2 feet or more above the horizontal plane or ground level.

3. Subarray Configuration.

The module shall be located in the interior of a $1.2 \mathrm{~m} \times 1.2 \mathrm{~m}$ (4' $x 4^{\prime}$ ) subarray. Black aluminum panels or other modules uf Lhe same design shall be used to fill in any rcmaining open area of the subarray structure. The back of the subarray shall be exposed.

4. Surrounding Area

There shall be no obstructions to prevent full irradiance of the module beginning a minimum of 4 hours before solar noon and up to 4 hours after solar noon. The ground surrourding the module shall not have a high solar reflectance and shall be flat and/or sloping away from the test fixture. Grass and various types of ground covers, blacktop, and dirt are recommended for the local surrounding area. Buildings having a large solar reflective finish shall not be present in the immediate vicinity. Good engineering judgment shall be exercised to assure that the module, front and back sides, is receiving a minimum of reflected solar energy from the surrounding area.

\section{WIIn! Diluction}

The wind shall not be predominantly from due east or from due west; flow parallel to the plane of the array is not acceptable and can result in a lower than typical operating cell. temperature.

6. Module'Electrical Load

Data shall be obtained for a mudule ojen-circuit condition correspondine to zoro electicical power gitput. 


\section{E. TEST EQUIPMENT}

\section{Pyranometer}

The total solar irradiance on the active side of the module shall be measured by a pyranometer mounted on the plane of the module and within $.3 \mathrm{~m}$ ( 1 foot) of the array. The pyranometer used shall have a traceable annual calibration to a recognized standard instrument and shall be either (1) a temperature-compensated unit which has less than $\pm 1 \%$ deviation in sensitivity over the range $-20^{\circ} \mathrm{C}$ to $440^{\circ} \mathrm{C}$, or (2) a unit which incorporates a temperature sensor and has a sensitivitytemperature correction supplied with its calibration.

\section{Wind Measurement}

Buth the wind dltecllum and wind speed shall be measured at the approximate height of the module and as near to the module as feasible.

\section{Air Temperature}

The Local air temperature shall be measured at the approximate height of the module. The measurement shall be made in the shadow of the module and shall be accurate to $\pm 1^{\circ} \mathrm{C}$. (Note: An average local air temperature is desired. This is obtained satisfactorily by increasing the thermal mass of the thermocouple by imbedding the thermocouple in a solder sphere of approximately 1/4-inch diameter.) The measurement must be appropriately shielded and vented.

\section{Celi Temperature}

The temperature of at least two representative interior solar cells shall be measured to $\pm 1^{\circ} \mathrm{C}$. Thermocouples shall be 36 gauge, and shall be soft-soldered directly to the back of the cells.

\section{Substrate Surface Temperature}

The exterior temperature of the rear of the solar module shall be measured to $\pm 1^{\circ} \mathrm{C}$ beneath a representative cell and when practical beneath a representative space between cells. Thermocouples shall be 26 gauge, and shall be bonded down with Eccobond $57 \mathrm{C}$ epoxy or the equivalent.

\section{F. DATA RECORDING}

All data shall be printed out approximately every 2 minutes. In addition, solar intensity, wind speed, wind direction, and air temperature shall be continuously recorded. 


\section{G. CLEANING}

The active side of the solar cell module and the pyranometer bulb shall be cleaned before the start of each test. Dirt shall not be a.llowed to build up. Cleaning with a mild soap solution followed by a rinse with distilled water has proven to be effective.

\section{H. EQUIPMENT CALIBRATION}

A calibration check shall be made of all the equipment prior to the start of the test.

I. TEST DESCRIPTION

The test description form illustrated in Figure A-3 shall be completed before the start of the test..

J. AUTOMATION

Once initiated, the data may be collected automatically. However, the equipment. shall be checked once every hour.

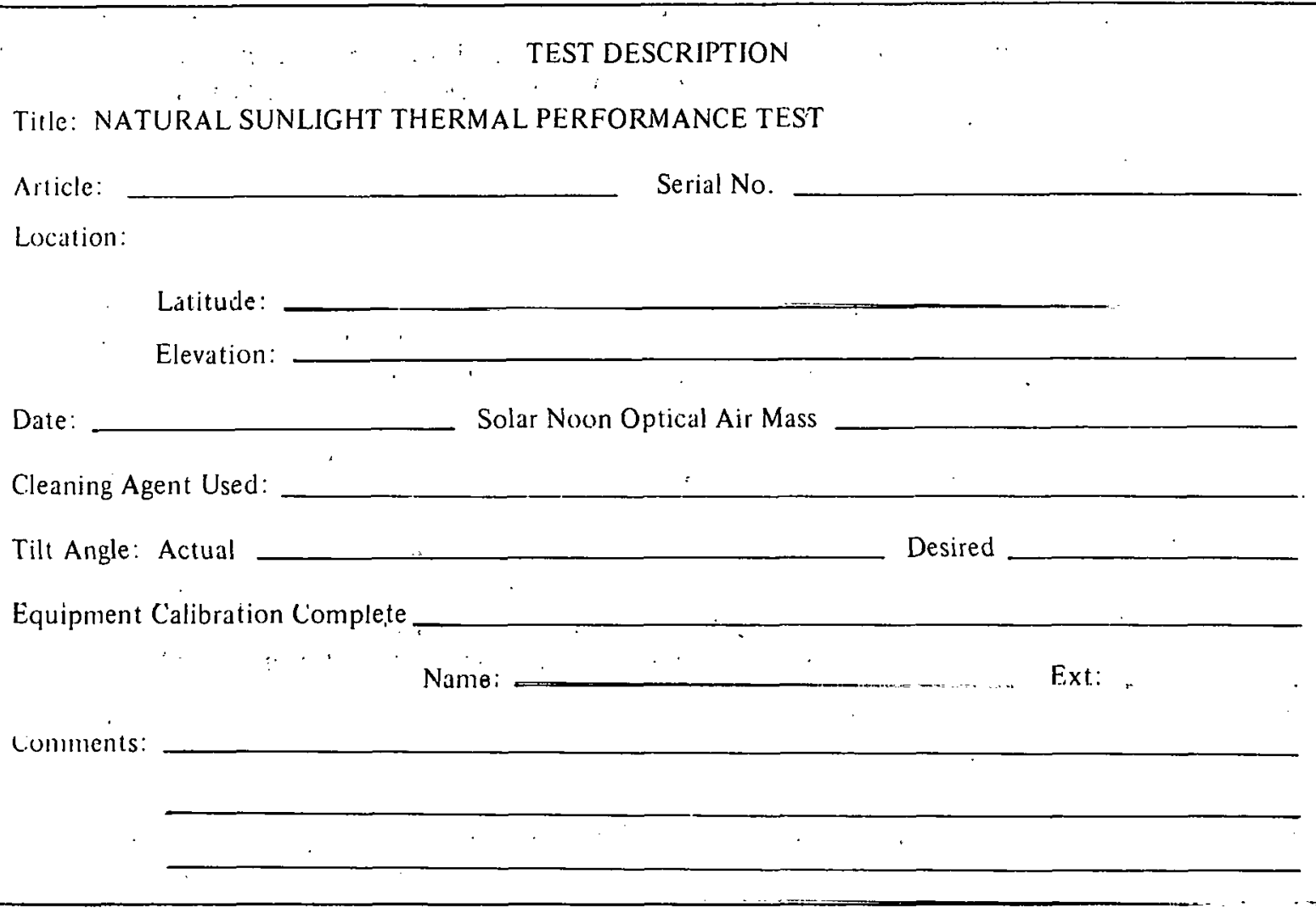

Figure A-3. Test Description Form 